\title{
Low-angle normal faults and seismicity: A review
}

\author{
Brian Wernicke \\ Division of Geological and Planetary Sciences, California Institute of Technology, Pasadena
}

\begin{abstract}
Although large, low-angle normal faults in the continental crust are widely recognized, doubts persist that they either initiate or slip at shallow dips $\left(<30^{\circ}\right)$, because (1) global compilations of normal fault focal mechanisms show only a small fraction of events with either nodal plane dipping less than $30^{\circ}$ and (2) Andersonian fault mechanics predict that normal faults dipping less than $30^{\circ}$ cannot slip. Geological reconstructions, thermochronology, paleomagnetic studies, and seismic reflection profiles, mainly published in the last 5 years, reinforce the view that active low-angle normal faulting in the brittle crust is widespread, underscoring the paradox of the seismicity data. For dip-slip faults large enough to break the entire brittle layer during earthquakes $\left(M_{w} \sim 6.5\right)$, consideration of their surface area and efficiency in accommodating extension as a function of dip $\theta$ suggests average recurrrence intervals of earthquakes $R^{\prime} \propto \tan \theta$, assuming stress drop, rigidity modulus, and thickness of the seismogenic layer do not vary systematically with dip. If the global distribution of fault dip, normalized to total fault length, is uniform, the global recurrence of earthquakes as a function of dip is shown to be $R \propto \tan \theta \sin \theta$. This relationship predicts that the frequency of earthquakes with nodal planes dipping between $30^{\circ}$ and $60^{\circ}$ will exceed those with planes shallower than $30^{\circ}$ by a factor of 10 , in good agreement with continental seismicity, assuming major normal faults dipping more than $60^{\circ}$ are relatively uncommon. Revision of Andersonian fault mechanics to include rotation of the stress axes with depth, perhaps as a result of deep crustal shear against the brittle layer, would explain both the common occurrence of lowangle faults and the lack of large faults dipping more than $60^{\circ}$. If correct, this resolution of the paradox may indicate significant seismic hazard from large, low-angle normal faults.
\end{abstract}

\section{Introduction}

It is appropriate for the 75th anniversary of the American Geophysical Union that recognition be given to the 50th anniversary of a paper by Longwell [1945]. Although not the first description of such phenomena [e.g., Ransome et al., 1910], the paper was remarkable in its documentation using maps, photographs, and cross sections of spectacularly exposed normal faults in the Las Vegas region, with displacements of 1-2 km and dips of $0-30^{\circ}$. In one large-scale exposure, since partly drowned beneath the waters of Lake Mead, a fault was observed to flatten downward, from about $30^{\circ}$ to $5^{\circ}$ over a crosssectional depth of $600 \mathrm{~m}$.

It is perhaps a measure of a theoretically based prejudice against low-angle normal faults that Longwell [1945] excluded regional crustal extension as a cause for faulting. He instead interpreted them to result from extension on the crests of large-scale compressional anticlines. Mechanical arguments for downward flattening (listric) normal faults date back at least to McGee [1883], but Hafner [1951], citing Longwell's [1945] observations, showed that certain loading conditions along the base of an elastic plate induce curvature of stress trajectories favorable for the formation of low-angle normal faults.

Despite both observation and theory, the assumption that the least principal stress direction is horizontal throughout an extending crust [e.g., Anderson, 1942] held sway for the suc-

Copyright 1995 by the American Geophysical Union.

Paper number 95JB01911.

0148-0227/95/95JB-01911\$05.00 ceeding three decades. Low-angle extensional structures, though documented by geological mapping studies, were interpreted as either peculiar thrust faults or surficial landsliding phenomena. Sliding and spreading of rootless, internally coherent, extended allochthons along faults dipping only a few degrees is well known. It includes cases where detachment occurs along incompetent horizons in sediments such as shale or salt, as developed over thousands of square kilometers in the northern Gulf of Mexico [Worrall and Snelson, 1989]. However, it also includes examples where the sliding occurs within competent horizons, as in the Ordovician dolostones along the Heart Mountain detachment [Pierce, 1957; Hauge, 1990]. These examples generally involve only the upper few kilometers of the crust and are not accompanied by coeval extension of the underlying continental basement. In contrast, fault systems in the Basin and Range, such as those described by Longwell [1945], clearly involve continental basement and are observed in some cases to cut structurally downward through $10 \mathrm{~km}$ or more of the crust.

Beginning with a handful of Basin and Range field studies [e.g., Anderson, 1971; Wright and Troxel, 1973; Proffett, 1977], it was not until the late 1970 s that the numerous documented low-angle normal faults gained a measure of acceptance as a direct expression of large-magnitude continental extension. At about the same time, it was also realized that many metamorphic tectonites in the Basin and Range previously thought to be Mesozoic or Precambrian in age were actually Tertiary [e.g., Davis and Coney, 1979]. In many cases these rocks lay in the footwalls of regionally extensive low-angle normal faults or "detachments" that could be traced for several tens of kilometers parallel to their transport directions. By 1980, it was clear 
(a)

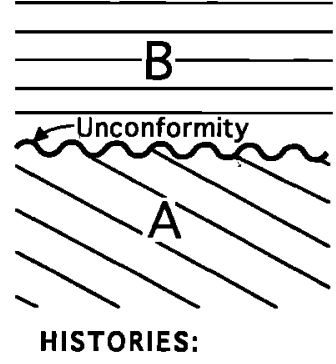

Deposition of $\mathbf{A}$

Tilting \& erosion Deposition of $\mathrm{B}$ Erosion (b)

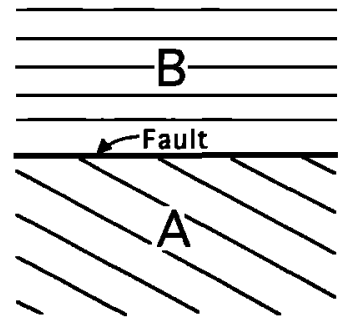

Deposition of $A$ Deposition of $\mathbf{B}$ Faulting of $B$ on $A$ Erosion

Figure 1. Contrast in geological history from interpreting a contact between older sedimentary sequence $\mathrm{A}$ and younger sequence $B$ as (a) an unconformity and (b) a low-angle normal fault.

that numerous isolated exposures of detachments and their metamorphic substrate formed a nearly continuous belt from Sonora, Mexico, to southern British Columbia, referred to as the Cordilleran metamorphic core complexes [Crittenden et al., 1980; Armstrong, 1982]. It was realized that the footwalls of many exposed detachments were not strongly metamorphosed in the Tertiary, raising the possibility that low-angle normal faults formed and were active entirely in shallow crust [e.g., Wernicke et al., 1985; Spencer, 1985; Dokka, 1986; John, 1987].

These observations ran counter to Jackson and White's [1989] descriptive synthesis of some 56 earthquakes on active continental normal faults. They concluded that (italics theirs)

Among the most important observations that now influence the debate are... that large earthquakes do not occur on listric faults that flatten at shallow depths (as originally thought: e.g. McKenzie, 1978a, b), but on faults that are steep throughout the seismogenic upper crust...

Whether or not this conclusion is correct is a first-order problem in understanding the structure and dynamics of the lithosphere.

\section{Geological Significance}

The recognition of low-angle normal faults and the core complex tectonic association is now global and includes oceanic lithosphere as well as the continents [e.g., Mutter and Karson, 1992]. The significance of these structures for geology as a whole may be illustrated by considering an unexposed low-angle contact roughly parallel to overlying, younger sedimentary unit B but discordant to underlying sedimentary (or metamorphic) unit A (Figure 1). Prior to 1980, many geologists would have interpreted such a contact as either an unconformity or a thrust fault. The possibility of the contact being a normal fault may have been overlooked on the basis that known low-angle fault contacts were restricted to thrusts, which generally emplace older rocks on younger. The geologic histories for these two cases are of course markedly different (Figure 1). The Basin and Range provides numerous case histories of the problem, where contacts between Tertiary and underlying pre-Tertiary strata, in some cases with high angle between the contact and Tertiary strata, were interpreted as unconformities. For example, low-angle contacts mapped by Kemnitzer [1937], Fritz [1968], and Dibblee [1970] as unconfor-

mities have since been documented to be low-angle normal faults (Davis et al. [1980], Gans et al. [1989], and Dokka [1986], respectively). Similarly, major low-ange fault systems interpreted as thrusts by Noble [1941], Misch [1960], and Drewes and Thorman [1978] are now widely regarded as normal faults related to Cenozoic extension (Wright and Troxel [1984], Miller et al. [1983], and Dickinson [1991], respectively). Reinterpretations currently underway in other mountain belts are similarly profound.

These Basin and Range field relations represented a class of geologic contact that had not been previously recognized as a fundamental tectonic element. Recognizing them as such is as basic to accurate historical inference in geology as, for example, the knowledge that rocks with igneous texture intrude their surroundings in a molten state.

\section{Mechanical Significance}

The fact that low-angle normal faults are not predicted by Andersonian theory is also fundamental to interpreting the stress state and physical constitution of the crust. In the 1980s, debate centered on the kinematics of generating the corecomplex association. Most current models suggest asymmetrical denudation along large normal faults that transect the upper $15-20 \mathrm{~km}$ of the crust at low angle, accompanied by isostatic rebound and flexure of the unloaded footwall [e.g., Wernicke, 1981; Howard et al., 1982; Allmendinger et al., 1983; Spencer, 1984; Wernicke, 1985; Davis et al., 1986; Wernicke, 1992]. Recently, controversy has centered on the initial dip and subsequent modification of these faults and the roles of footwall metamorphic tectonite and magmatism.

This paper addresses the question: Are brittle low-angle normal faults active while at low dip? A number of authors have expressed doubt that shallowly dipping normal faults are important features in the extending seismogenic crust, pointing to Andersonian theory and a lack of seismicity on such faults [e.g., Buck, 1988; King and Ellis, 1990]. A large body of literature has nonetheless focused on non-Andersonian explanations for active low-angle normal faulting [e.g., Xiao et al., 1991; Forsyth, 1992; Axen, 1992; Parsons and Thompson, 1993]. If low-angle normal faults are indeed active in the seismogenic crust, why are there so few, if any earthquakes observed on them? Evidence summarized below, mostly published in the last 5 years, tends to reinforce this paradox. A simple mechanical model relating fault dip to earthquake recurrence is developed that may provide an explanation.

\section{Observations of Low-Angle Normal Faults}

Andersonian theory predicts that extension of the crust results in faults that initially dip $60^{\circ}$ but provides no insight as to how such faults with large finite slip develop kinematically. For example, normal faults may rotate during and after their slip history, as in the case of a system of "domino-style" or "bookshelf" fault blocks [Wernicke and Burchfiel, 1982], in which case, dips lower than $60^{\circ}$ are generally expected [e.g., Thatcher and Hill, 1991]. The key questions are whether a given fault in the seismogenic part of the crust was active at shallow dip, and whether the fault initiated at shallow dip. Low-angle normal faults present no conflict with Andersonian theory if, for example, they initiate at $60^{\circ}$ and rotate down to $30^{\circ}$ while active and are then further rotated to very low angle while inactive by a younger set of domino-style faults [Morton and Black, 1975; Proffett, 1977; Miller et al., 1983]. Clearly, many low-angle normal faults, including most of those described by Longwell 
[1945], cut upper crustal sedimentary layers at high angle and therefore probably had steep original dip.

A compilation of all well-determined focal mechanisms of normal fault earthquakes $\left(M_{w}>5.2\right.$, using momentmagnitude scale of Kanamori [1977]) in continents with nearly pure dip-slip movement (56 events) showed that most nodal planes dip between $30^{\circ}$ and $60^{\circ}$ [Jackson, 1987; Jackson and White, 1989]. A subset of those events where the fault plane is resolved by surface rupture (15 events) showed no faults with dip less than $30^{\circ}$. Based on this survey, many workers have stressed the uniformitarian interpretation ("the present is the key to the past") that all low-angle normal faults dipping less than $30^{\circ}$ are rotated while inactive from dips greater than $30^{\circ}$, either by younger high-angle faults or by isostatic adjustment [e.g., Buck, 1988; Gans et al., 1989; King and Ellis, 1990].

Others argued that although such rotations may be common, initiation and slip on shallow ( $<15 \mathrm{~km}$ depth) normal faults are required by geological and geophysical data [e.g., Wernicke et al., 1985; John, 1987; Wernicke and Axen, 1988; Davis and Lister, 1988; Yin and Dunn, 1992; Scott and Lister, 1992; Dokka, 1993; Axen, 1993]. These data include geologic reconstructions and fault rocks associated with detachments, thermochronologic and paleomagnetic investigations of exposed detachment footwalls, and seismic reflection profiles.

\section{Geologic Reconstructions}

A direct approach to resolving whether normal faults either slip or initiate at low-angle is restoration of well-constrained geologic sections. In the U.S. Cordillera, some low-angle normal faults cut abruptly downward through $10 \mathrm{~km}$ or more of preextensional strata and crystalline basement (e.g., Mojave Mountains, Arizona [Howard and John, 1987]; Egan Range, Nevada [Gans et al., 1989]; South Virgin Mountains, Nevada [Fryxell et al., 1992]; and Priest Lake area, Idaho [Harms and Price, 1992]). These fault systems cut through uppermost crustal levels $(<1 \mathrm{~km})$ at their shallow ends. In other instances, however, the increase in footwall structural depth is small in comparison to exposed downdip length of the footwall. This seems especially true where detachment systems cut across wide $(30-50 \mathrm{~km})$ areas of deeper crustal rocks $(\sim 5-15 \mathrm{~km}$ paleodepth), as in most core complexes. Some examples include the Raft River Range, Utah [Compton et al., 1977; Malaveielle, 1987; Manning and Bartley, 1994]; the Ruby Mountains-East Humbolt Range area, Nevada [Mueller and Snoke, 1993]; the Black Mountains, California [Holm et al., 1992]; the Chemehuevi Mountains, California [John, 1987]; the Harcuvar and Buckskin Mountains, Arizona [Spencer and Reynolds, 1991]; the South Mountains, Arizona [Reynolds, 1985]; and the Catalina-Rincon Mountains, Arizona [Dickinson, 1991]. In some instances, however, faults transect even the upper 7-8 $\mathrm{km}$ of the crust at low average initial dip [e.g., Wernicke et al., 1985; Axen, 1993].

An example of the latter may be found in the Mormon Mountains-Tule Springs Hills area of southern Nevada [Wernicke et al., 1985; Axen et al., 1990; Axen, 1993]. Two Miocene detachments are superimposed on the frontal decollement thrust of the Cordilleran fold and thrust belt [e.g., Burchfiel et al., 1992], including the Mormon Peak detachment [Wernicke et al., 1985] (Figure 2) and the Tule Springs detachment [Axen, 1993]. The Mormon Peak detachment cuts downward from the hanging wall of the thrust into its footwall (Figure 2), such that the angles between the detachment and (1) the thrust ramp and subparallel allochthonous strata and (2) the autochthonous strata below the thrust are defined within a few degrees ( $\alpha$ and $\beta$, respectively, Figure 3). The angles between prerift Miocene volcanic and sedimentary strata and (1) strata in the thrust ramp and (2) autochthonous strata of the foreland just in front of the thrust plate are also well defined ( $\gamma$ and $\delta$, respectively, Figure 3). Assuming west dipping allochthonous strata of the thrust ramp zone above and below the detachment were parallel, the dip of the detachment with repect to the prerift Miocene strata is

$$
\theta_{\iota}=\gamma-\alpha \approx 20^{\circ} \text {. }
$$

Thrust loading presumably would have deflected the autochthous strata to westward $\operatorname{dip} \phi$ relative to the undeformed foreland (Figure 3). For undisturbed thin-skinned foreland thrust belts worldwide and especially the Cordilleran belt, this deflection is generally no more than about $5^{\circ}$ [e.g., Price, 1981; Royse et al., 1975; Allmendinger, 1992; Royse, 1993]. Assuming low $\phi$,

$$
\theta_{\imath}<\beta+\phi+\delta<27^{\circ} .
$$

Therefore two independent observations, (1) the detachment's relations with the thrust ramp and overlying Tertiary and (2) its relations with the thrust autochthon and overlying Tertiary, both suggest an initial dip of the Mormon Peak detachment of about $20^{\circ}-27^{\circ}$ [Wernicke et al., 1985].

The initial dip of the Tule Springs detachment is also clearly defined [Axen, 1993] (Figure 3). The detachment runs subparallel to the thrust plane where it overrides autochthonous strata for a horizontal distance of at least $10 \mathrm{~km}$. Thus the detachment initiated at the dip of the decollement thrust and the authochthonous strata prior to extension. In addition to this constraint, the unconformity between synrift strata and allochthonous strata is not markedly angular (Figure 3). Detailed consideration of these constraints, including reconstruction of the detachment's hanging wall, suggest an initial dip in the range $3^{\circ}-15^{\circ}$ [Axen, 1993].

The Mormon Mountains-Tule Springs Hills detachment system is among the best exposed upper crustal, low-angle normal fault systems in the world, but it is not clear how typical its low upper crustal initiation angles are compared with active slip at low angle on more deeply exhumed structures. The anisotropy of shallowly west dipping thrusts and bedding in the thinskinned thrust belt may have somehow played a role in generating the low initial dips. Seismic reflection data to the north along the frontal Cordilleran thrust belt also suggest shallow crustal normal faults with low initial dips developed just west of the frontal thrusts [e.g., Bally et al., 1966; Royse et al., 1975; Allmendinger et al., 1983; Smith and Bruhn, 1984; Planke and Smith, 1991]. The Mormon Mountains-Tule Springs Hills area lies at a point where these extensional structures begin to cut southward well into the cratonic foreland of the thrust belt, thereby exhuming the frontal most thrusts from paleodepths of 7-8 km.

A second example of shallowly dipping normal faults in the uppermost crust occurs in the Whipple Mountains area of southeastern California and west central Arizona [Davis and Lister, 1988; Scott and Lister, 1992]. There, several large areas of hanging wall synrift strata (either flat-lying or cut by highangle normal faults of opposing dips) are truncated from below by the very shallowly dipping Whipple-Buckskin detachment system. The depth to the active detachment system, con- 

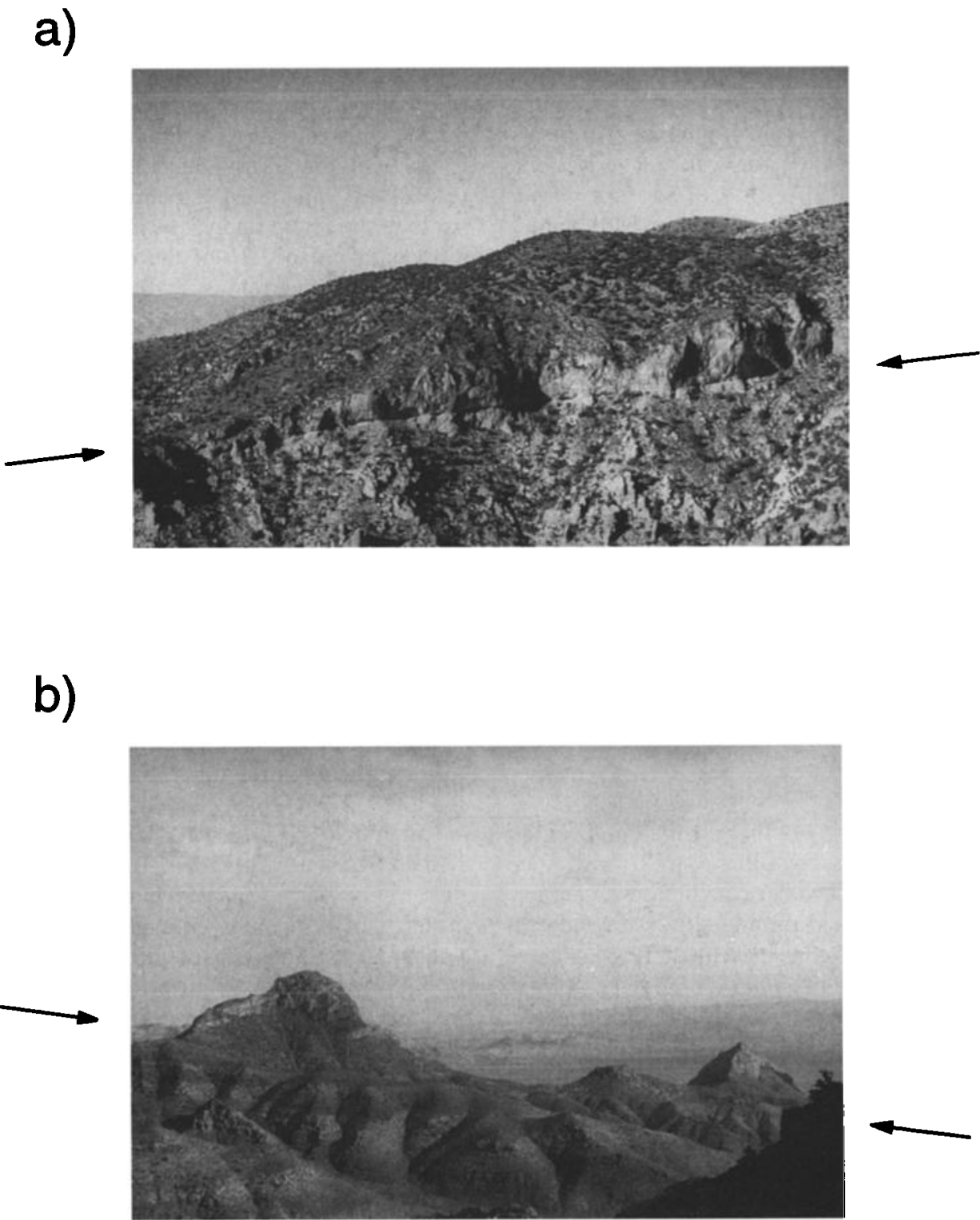

Figure 2. Photographs of Mormon Peak detachment, Nevada. (a) Looking north, western Mormon Mountains, fault (between arrows) emplaces Carboniferous strata over Cambrian. Cliff on right side is approximately $50 \mathrm{~m}$ high. (b) Looking south, western Mormon Mountains, detachment (planar topographic bench between arrows) cuts at about $5^{\circ}$ across footwall Cambrian strata (light and dark banding, lower left). Hanging wall comprises three blocks of imbricately normal faulted Ordovician through Carboniferous strata, variably tilted to the left. There is approximately $600 \mathrm{~m}$ of relief from valley in foreground to high peak on left.

strained by the thickness of synextensional strata, was less than 2-3 km. These relations argue strongly for a low initial dip for the fault initially cutting through hanging wall strata, although it does not constrain the trajectory through the footwall, which likely had a more complex history [Davis and Lister, 1988]. In addition, the base of a large syntectonic landslide mass derived from the exposed footwall was deposited across the detachment system subparallel to the fault plane, offset some $10 \mathrm{~km}$ along it, and later cut by normal faults which are in turn cut by the detachment [Yin and Dunn, 1992].

Field geologic relations are fundamental to understanding detachment geometry and kinematics. Additional data, including thermochronology, paleomagnetic data, seismic reflection profiling, and seismicity, are required to test competing models for their evolution. In general, geologic reconstructions suggest a biplanar or listric geometry for major normal faults, with highly variable depth of flattening ranging from less than $5 \mathrm{~km}$ to more than $10 \mathrm{~km}$ preextensional depth [e.g., Spencer and Reynolds, 1991; Wernicke, 1992], a conclusion largely reinforced by these additional data.

\section{Thermochronologic Data}

An important tool for addressing the original configuration of crustal-scale normal faults is the thermal history of their footwalls, especially where there are wide exposures in the transport direction of the fault. Published applications of this method include just a few examples, mainly in the central and southern Basin and Range, and so the results may be geographically biased. Generally, the time of footwall unroofing is 


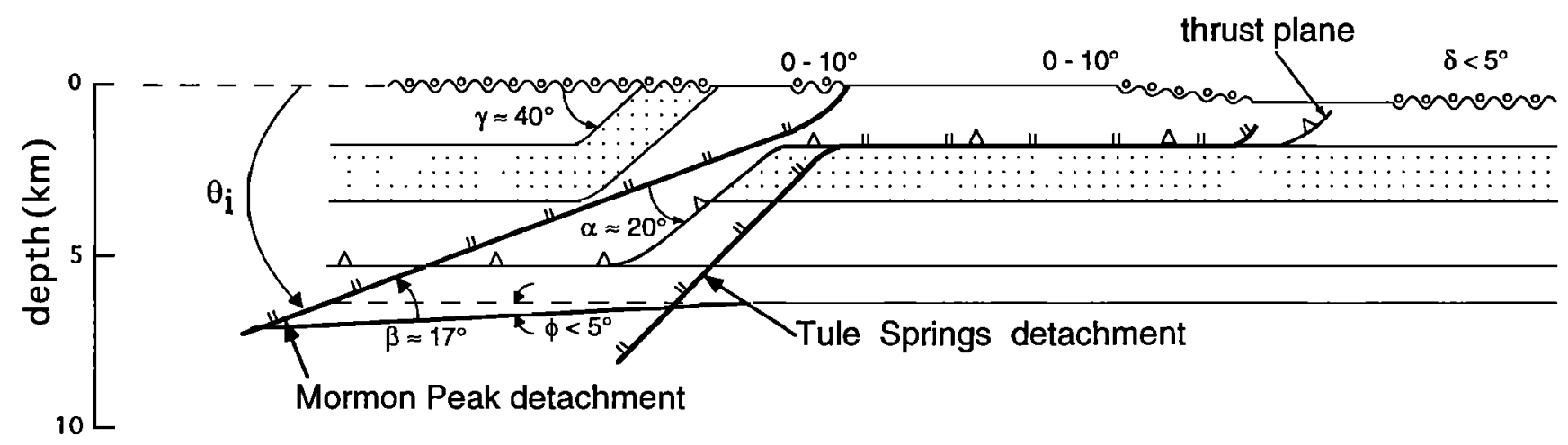

Figure 3. Reconstruction of Mormon Peak and Tule Springs detachments, slightly modified from Axen et al. [1990] and Axen [1993] for clarity. Thick lines with double ticks, detachments; line with teeth, thrust fault; wavy line with dots, sub-Tertiary unconformity; other thin lines, various stratigraphic contacts. See text for discussion.

clearly expressed by rapid cooling events between $400^{\circ} \mathrm{C}$ and $100^{\circ} \mathrm{C}$. The ambient temperature of most footwalls (excluding cooling of synrift plutons) is usually well below the Ar retention temperature in hornblende $\left(450-500^{\circ} \mathrm{C}\right)$ and close to that for retention in micas, or about $300-400^{\circ} \mathrm{C}$ [e.g., Richard et al., 1990; John and Foster, 1993; Holm and Dokka, 1993; Dokka, 1993]. A pattern emerging from these studies in the Cordillera is that deeper portions of the footwall cool from these temperatures to less than $100^{\circ} \mathrm{C}$ (fission track annealing temperature in apatite) in a period of 1-10 m.y. [e.g., Holm and Dokka, 1993].

In most examples it is possible to establish the maximum variation in temperature across the exposed footwall immediately prior to the thermal perturbation caused by unroofing. Given the downdip temperature variation across the footwall prior to unroofing, the average dip of the fault can be determined for variable assumptions of the preextensional geothermal gradient. This technique has been employed for a number of extensional terrains in the Cordillera, where footwall strain, including elongation via detachment-related shearing or postdetachment normal faulting, and transient effects from syntectonic intrusions, may be taken into account. The paleothermal field gradient (preunroofing, downdip thermal gradient of the exposed footwall) between two points $\mathrm{A}$ and $\mathrm{B}$ with temperature difference $\Delta T$ is related to the paleogeothermal gradient by the average dip of the fault (Figure 4), which is

$$
\theta=\sin ^{-1} \frac{d T / d w}{d T / d z}
$$

where $d T / d z$ is the geothermal gradient just prior to unroofing and $d T / d w$ is the measured field paleothermal gradient.

The overall range of field paleothermal gradient, with uncertainties, is $0-33^{\circ} \mathrm{C} / \mathrm{km}$, measured across downdip distances of 6-40 km (Figure 4). The two highest gradients are from the upper 5-10 km paleodepth (Piute and Harcuvar detachments, shown as solid symbols in Figure 5), while the other, deeper examples range from 0 to $19^{\circ} \mathrm{C} / \mathrm{km}$.

The ambient geothermal gradient in the Basin and Range prior to unroofing has been determined in several areas where the time-temperature history has been determined from rocks of independently estimated paleodepth. For eastcentral Nevada, the average geothermal gradient at 35 Ma was about $20^{\circ} \mathrm{C} / \mathrm{km}$ in the upper $10 \mathrm{~km}$ of the crust prior to unroofing [Dumitru et al., 1991]. In the Gold Butte area of southern Nevada, an apatite fission track study indicates a gradient of about $25-30^{\circ} \mathrm{C} / \mathrm{km}$ at $15 \mathrm{Ma}$ in the upper $3-4 \mathrm{~km}$ of the crust [Fitzgerald et al., 1991]. In the eastern Mojave Desert region, rather higher gradients at about $18 \mathrm{Ma}$ of $50 \pm 20^{\circ} \mathrm{C} / \mathrm{km}$ for the Piute Mountains and a range of $30-50^{\circ} \mathrm{C} / \mathrm{km}$ for the Chemehuevi Mountains have been suggested [Foster et al., 1991; John and Foster, 1993]. In the Death Valley region, ambient temperatures at $10-15 \mathrm{~km}$ depth at 8-10 Ma were about 300$350^{\circ} \mathrm{C}$, suggesting a range of $25-35^{\circ} \mathrm{C} / \mathrm{km}$ [Holm and Wernicke, 1990; Holm et al., 1992]. Possible gradients near or above $50^{\circ} \mathrm{C} / \mathrm{km}$ in the eastern Mojave region are determined for a time near the end of a major magmatic episode and are probably relatively transient. Thus a range in gradients of 20$35^{\circ} \mathrm{C} / \mathrm{km}$ would probably represent the average upper crustal paleogeothermal gradient in most areas of the Basin and Range since mid-Tertiary time, in agreement with the geotherms of $L a$ chenbruch and Sass [1978], with magmatic and extensional strain locally raising it to 2 or perhaps 3 times that amount.

A plot of field paleothermal gradient determined from Figure 5 versus paleogeothermal gradient, contoured in initial dip according to equation (1), is shown in Figure 6. In these examples, fault rocks show evidence of brittle extensional faulting and cataclasis, but major bulk elongations of the entire footwall block, particularly in the brittle field, are unlikely. These data suggest that although some sections yield dips as high as $45^{\circ}-60^{\circ}$ at the extremes of their uncertainties, most of the data suggest initial dips of less than $30^{\circ}$. The two examples yielding the highest dips (SW Harquahala Mountains and Piute Range) involve relatively short transects across uppermost parts of the crust (Figure 6). The Gold Butte example may also have a high average dip (up to $45^{\circ}$ ), but it too involves uppermost crustal rocks in its shallow part $(<5 \mathrm{~km}$ paleodepth) where the denuding fault originally dipped about $60^{\circ}$ [Fryxell et al., 1992; Fitzgerald et al., 1991], and hence the fault probably flattened downward to its deepest exposures in order

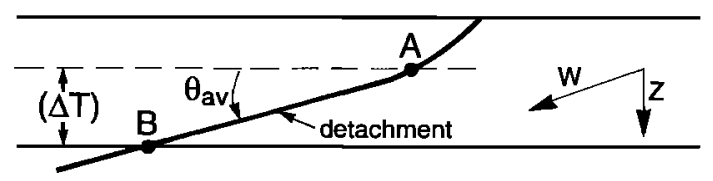

Figure 4. Diagram showing variables used to derive relationship between field paleothermal gradient, paleogeothermal gradient, and fault dip between points A and B (equation (1)). See text for discussion. 


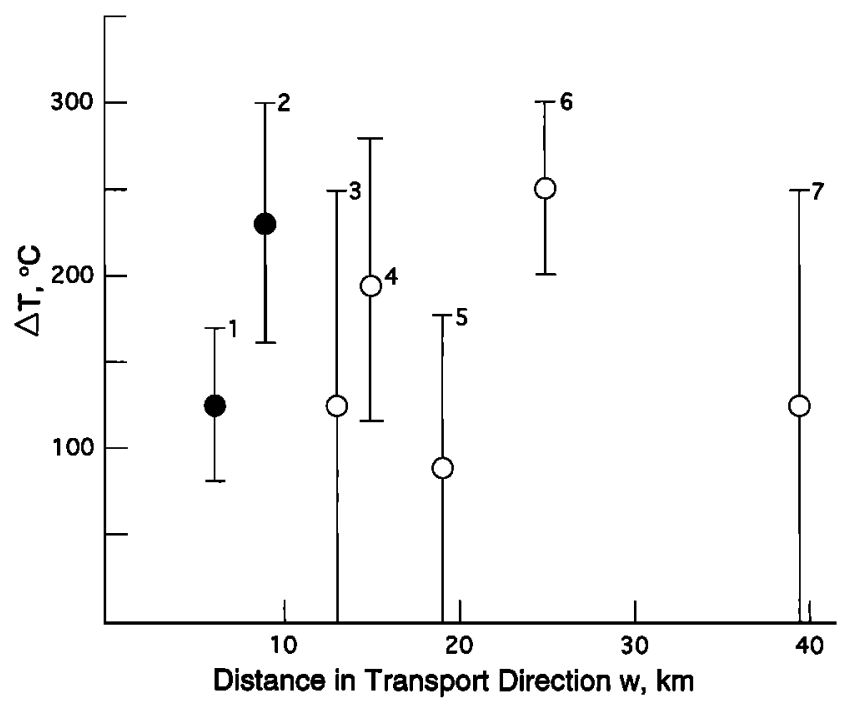

Figure 5. Maximum variation of paleotemperature in downdip direction across footwalls of Cordilleran detachments, just prior to unroofing. Solid symbols indicate upper crustal sections only. Locations and sources: 1 , Piute Mountains detachment, eastern Mojave Desert, California [Foster et al., 1991]; 2, southwestern Harcuvar Mountains, west central Arizona [Richard et al., 1990]; 3, Garden Wash detachment, South Virgin Mountains, Nevada [Fitzgerald et al., 1991; Fryxell et al., 1992; J. E. Fryxell, unpublished data 1994]; 4, Chemehuevi Mountains detachment, lower Colorado River trough, California [John and Foster, 1993]; 5, Newberry Mountains detachment, central Mojave Desert, California [Dokka, 1993]; 6, Amargosa detachment, Death Valley region, California [Holm and Wernicke, 1990; Holm et al., 1992; Holm and Dokka, 1993]; 7, Buckskin-Rawhide detachment, lower Colorado River trough, Arizona [Richard et al., 1990; Spencer and Reynolds, 1991].

to maintain even a high extreme of average dip at $45^{\circ}$. The remaining four examples, all from relatively wide, deep exposures, suggest average initial dips of $30^{\circ}$ or less.

In summary, thermochronogy that allows comparison of field paleothermal gradient with paleogeothermal gradient prior to unroofing is a useful means of constraining the initial configuration of large normal faults. In general, the field gradient is less than $1 / 2$ the value of the paleogeothermal gradient, corresponding to initial fault dips of $30^{\circ}$ or less (equation (1)). Faults where the initial dip may be significantly over $30^{\circ}$ seem to be restricted to high crustal levels.

\section{Paleomagnetic Data}

Paleomagnetic studies are also a potentially useful method for determining the initial dip of normal faults. If pretilt or syntilt magnetizations can be identified, they provide quantitative estimates, at relatively high precision, of the original and syntectonic dip of the detachment. To date, only two such studies have been published for core complexes with wide downdip exposures of midcrustal rocks, including the South Mountains, Arizona [Livaccari et al., 1993, 1995], and the Black Mountains, California [Holm et al., 1993]. In both areas, largely undeformed intrusive rocks from the detachment footwalls span much of the history of ductile deformation and rapid unroofing.

The South Mountains footwall is exposed for approximately $20 \mathrm{~km}$ in the transport direction and is composed of Protero- zoic basement intruded by four groups of intrusives, including two discrete plutons and two sets of younger dikes [Reynolds, 1985]. Superposition relations of the intrusive suite indicate unroofing and ductile shearing began shortly after intrusion of the older pluton [Reynolds, 1985]. The older dikes intruded late in the history of ductile deformation, while the younger dikes intruded during brittle deformation, late in the unroofing history [Livaccari et al., 1993, 1995; Fitzgerald et al., 1993]. Thermochronologic data indicate rapid cooling of footwall rocks between 22 and $17 \mathrm{Ma}$, from solidus temperatures in the oldest intrusion to $300^{\circ} \mathrm{C}$ between 22 and $20 \mathrm{Ma}$, then from $300^{\circ} \mathrm{C}$ to below $100^{\circ} \mathrm{C}$ from 20 to $17 \mathrm{Ma}$ [Fitzgerald et al., 1993].

Paleomagnetic data indicate concordance of high-coercivity, high unblocking temperature magnetizations with early Miocene expected directions for all four intrusive suites [Livaccari et al., 1993, 1995]. These data suggest unroofing along a fault with initial dip of about $10^{\circ}$.

The Black Mountains example has a more complex history. In structurally deep portions of the detachment footwall, an 11.7 Ma mafic intrusive complex is locally ductilely deformed and folded along with Proterozoic country rocks [Asmerom et al., 1990; Holm and Wernicke, 1990; Mancktelow and Pavlis, 1994]. It is intruded by silicic plutons and mafic to silicic dikes ranging in age from $\sim 9$ to $6.5 \mathrm{Ma}$ which largely escaped ductile deformation [Holm et al., 1992]. Rapid cooling and unroofing of the entire complex from over $300^{\circ} \mathrm{C}$ to less than $100^{\circ} \mathrm{C}$ occurred between $\sim 8.5$ and $6.0 \mathrm{Ma}$ [Holm and Dokka, 1993].

High unblocking temperature, high-coercivity magnetizations from the younger group of intrusions may be restored to their Miocene expected directions by a $50^{\circ}-80^{\circ}$ counterclockwise rotation about a vertical axis, interpreted as deformation associated with postunroofing dextral-oblique shear on the Death Valley fault zone [Holm et al., 1993; Mancktelow and Pavlis, 1994]. These plutons do not show a significant inclination anomaly. Subtracting the vertical axis rotation from the directions in the early mafic intrusion, an additional tilt of, in total, some $20^{\circ}-40^{\circ}$ is required to restore the mean direction from this intrusion into agreement with a Miocene expected direction [Holm et al., 1993]. There is considerable between-

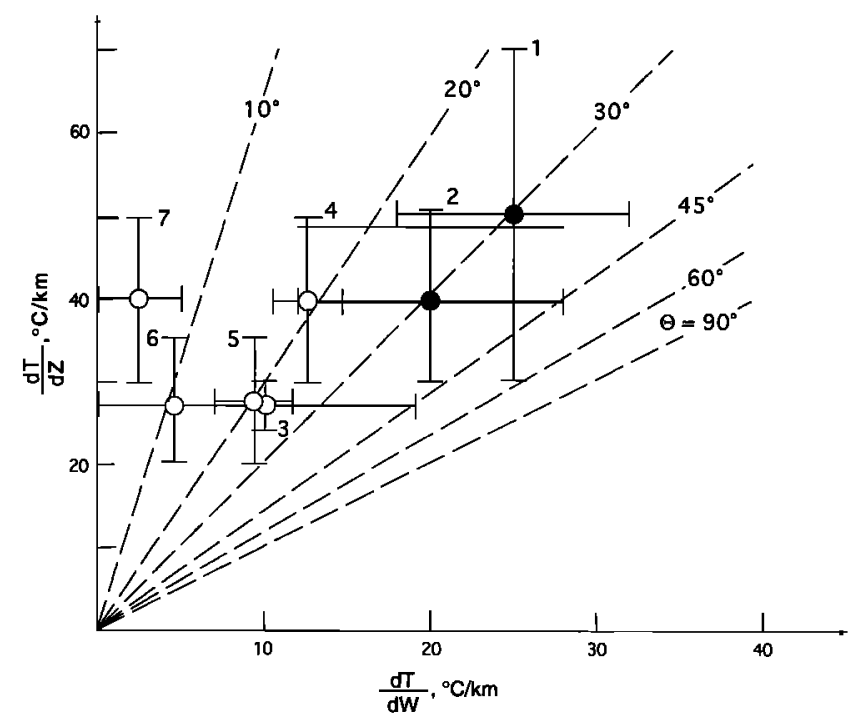

Figure 6. Plot of paleogeothermal gradient $d T / d z$ versus field paleothermal gradient $d T / d w$ for the seven detachments; solid symbols indicate upper crustal examples from Figure 5. 
site dispersion (up to $90^{\circ}$ ) in high-temperature, high-coercivity magnetizations from the mafic complex, possibly resulting in part from postintrusive folding, and thus it is difficult to precisely determine the net tilt. However, since the oldest silicic plutons predate rapid cooling of the complex, little or no net tilt occurred during unroofing between 8.5 and $6.0 \mathrm{Ma}$. Thermochronologic data suggest rapid unroofing is time transgressive in a downdip direction, which may support the concept of a "rolling hinge" (discussed in more detail below) moving through the footwall rocks during denudation, and thus it is possible the detachment may have briefly had a steeper dip during unroofing [Holm and Dokka, 1993; Holm et al., 1993].

These two examples, while both suggesting little net tilt as a result of unroofing, also demonstrate the potential of the approach, especially for crystalline rocks that characterize many detachment footwalls. Contrasts in the overall history of the two examples, however, suggests many surprises lie ahead for paleomagnetic studies of detachment complexes.

\section{Seismic Reflection Profiles}

Interpretations of seismic reflection data have played a major role in developing an awareness of low-angle normal faults, particularly in the geophysical community [e.g., Bally et al., 1981; Wernicke and Burchfiel, 1982; Allmendinger et al., 1983; Smith and Bruhn, 1984]. Hundreds of profiles, most of them unpublished, from a broad spectrum of extensional environments show strong, shallowly dipping reflections from lowangle fault planes that bound asymmetric half graben, often projecting up to surface exposures of the faults. These data strongly suggest low-angle $\left(<30^{\circ}\right)$ normal faults are common features in the upper $15 \mathrm{~km}$ of the continental crust.

Because the data are usually proprietary, the exact location of the line, velocity control, and the possible effects of migration are often not presented in publications. Thus with much of the data, "sideswipe" of a steeper fault such that it appears to be low-angle, "pull-down" of the shallow part of the fault due to low-velocity basin fill, and steepening of the fault plane reflection upon migration are important caveats in evaluating whether any given fault is a low-angle normal fault. However, such data are normally acquired perpendicular or parallel to structural trends in the area, mitigating the problem of sideswipe. Pull-down is also not usually a major effect on fault dip. For a typical section, the shallow part of the normal fault is imaged downdip for at least $10 \mathrm{~km}$, structural relief on the basin fill-bedrock contact in the hanging wall is less than $3 \mathrm{~km}$, and basin fill velocity is on average greater than half that of bedrock (e.g., parameters for a typical basin in the Basin and Range [Smith et al., 1989]). Using these extremes for a 10-km segment of fault, the apparent dip on a time section is no more than $10^{\circ}-12^{\circ}$ less than the true dip. Migration of reflections also serves to steepen dips but at large scale with dips less than $30^{\circ}$ the dip of a given reflection is not significantly increased.

Among the best documented images of shallow listric fault phenomena are from the northern Gulf of Mexico, where large-scale slumping of passive margin shelf strata toward the slope along a salt decollement is the underlying cause of faulting, rather than whole crust extension [e.g., Worrall and Snelson, 1989].

The most spectacular seismic image of a basement-involved, upper crustal low-angle normal fault (or for that matter, of any fault) is the Consortium for Continental Reflection Profiling (COCORP) and related profiles across the Sevier Desert de- tachment in the Basin and Range province of west central Utah [Allmendinger et al., 1983]. This profile revealed a strong, continuous, multicyclic reflection that cuts from the surface, along a major range front, down to over $5 \mathrm{~s}$ two-way travel time (12-15 km depth) with an average dip of $12^{\circ}$ to the west [Allmendinger et al., 1983, Figure 2]. As shown by a grid of industry profiles and well data along its shallow, eastern portion, Cenozoic half graben above the reflection are bounded by relatively steep faults that do not offset it [e.g., McDonald, 1976; Planke and Smith, 1991]. These data also show that the detachment covers an area of at least $7000 \mathrm{~km}^{2}$.

The position of the reflection within the east directed Cordilleran thrust belt led to the early interpretation that the reflection was a thrust fault, reactivated as a Cenozoic extensional structure [e.g., McDonald, 1976]. The geometric similarity of the seismic profiles to exposed Cordilleran detachment systems led to the suggestion that the reflection was primarily a Cenozoic normal fault which may not have been a reactivated thrust, since many detachments do not appear to reactivate old thrusts [Wernicke, 1981; Anderson et al., 1983; Allmendinger et al., 1983; Wernicke et al., 1985; Allmendinger et al., 1986] (Figure 2).

This long-standing interpretation of well and reflection data has recently been challenged, primarily based on a comparison of microstructures from drill cuttings taken near the reflection with those of the Muddy Mountain thrust, a major decollement thrust fault in southern Nevada [Anders and Christie-Blick, 1994]. In two wells, the reflection is a contact between Tertiary sandstone and Paleozoic carbonate, while the Muddy Mountain thrust emplaces Paleozoic carbonate over Mesozoic sandstone. Along the Muddy Mountain thrust, microfracture density in cataclasites within a few meters of the fault is at least a factor of three higher than in surrounding rocks [Brock and Engelder, 1977]. The cuttings, however, revealed no evidence of dense microfracturing near the contact, which was therefore interpreted as an unconformity rather than a fault [Anders and Christie-Blick, 1994].

The difficulties in establishing any contact relation from well cuttings are considerable, since a given set of cuttings samples a $10-\mathrm{m}$ interval. It is not known what is being sampled in the size fraction preserved as cuttings. For example, prefractured grains of the cataclasite may not survive pulverization by drilling. It is also possible that cataclasites on large detachments do not develop microfractures in the same way as thrusts or that thick cataclastic zones on detachments may be locally excised by faulting. Further tests, including analysis on cuttings recovered from known fault zones and on pulverized and unpulverized samples from surface-exposed low-angle normal faults, will be required to evaluate this technique. Other problematical aspects of their interpretations are discussed by Allmendinger and Royse [1995] and Otton [1995].

Interpretations of the Sevier Desert detachment notwithstanding, three examples, one from the Bohai Gulf in northern China, one from the Gulf of Oman, and one from the Basin and Range, are typical of profiles from areas of basementinvolved continental extension (Figure 7) and include intracratonic rift, passive margin shelf, and orogenic "collapse" tectonic settings, respectively.

The Gulf of Bohai resides within the Sino-Korean craton, more than $500 \mathrm{~km}$ west of its boundary against the Pacific plate. The imaged fault (Figure 7a) and associated half graben is one of over 50 such basins known from the region [Zhang, 1994]. The fault plane is listric, with an apparent dip of about 
a)

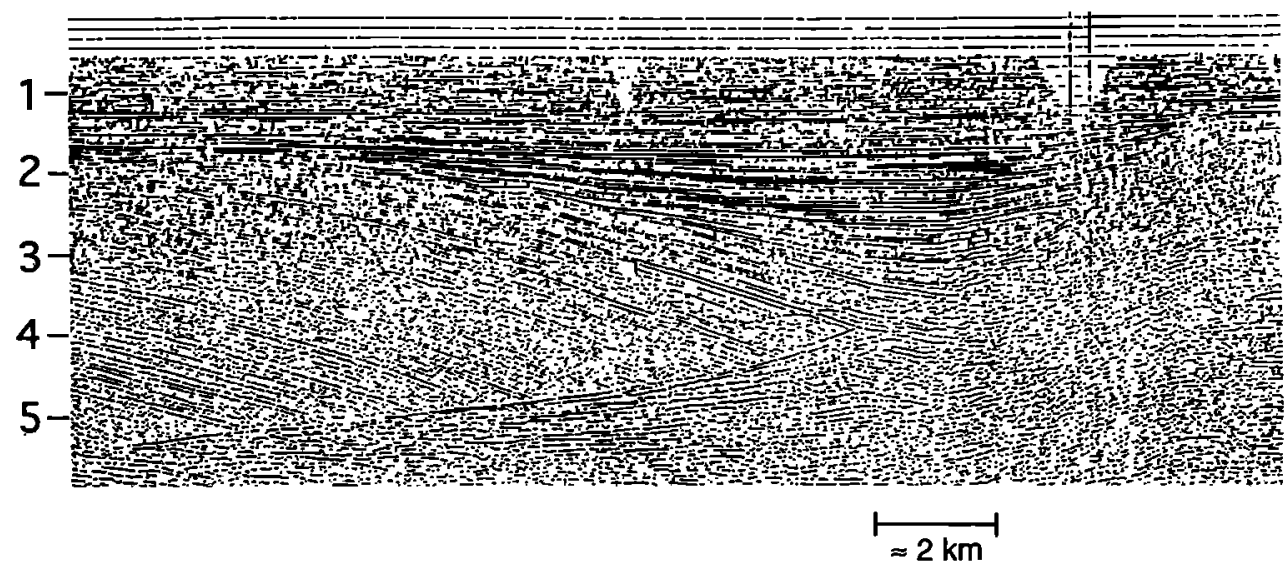

b)

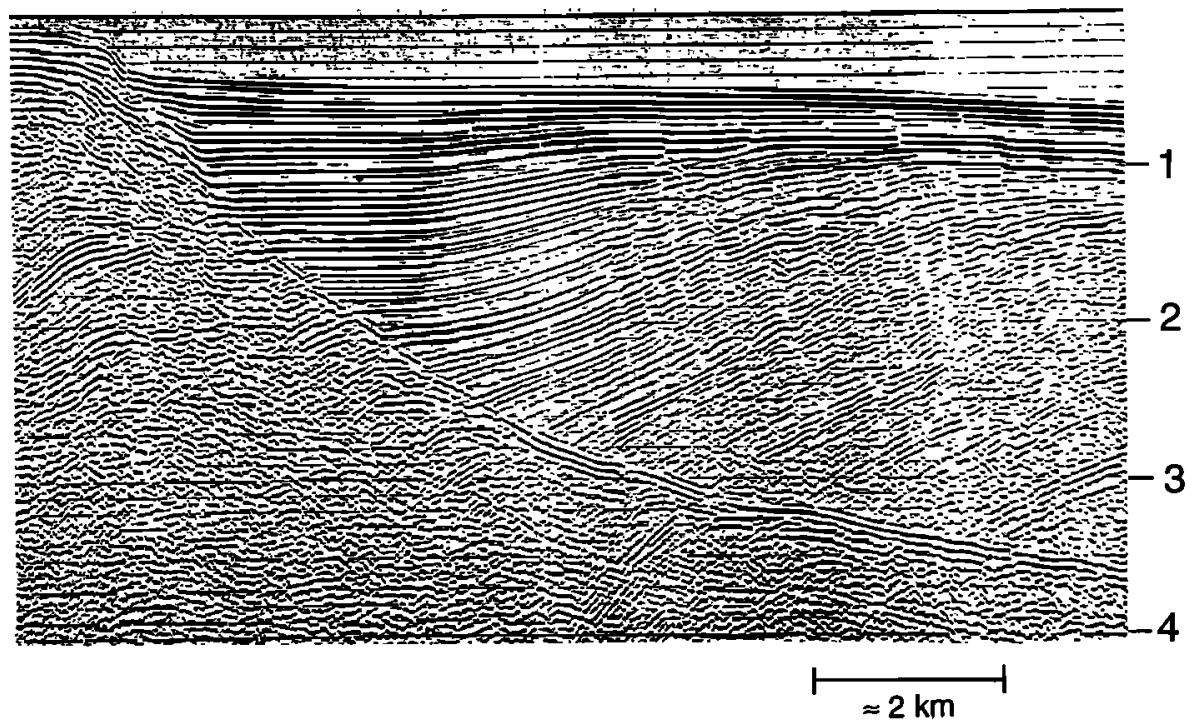

c)

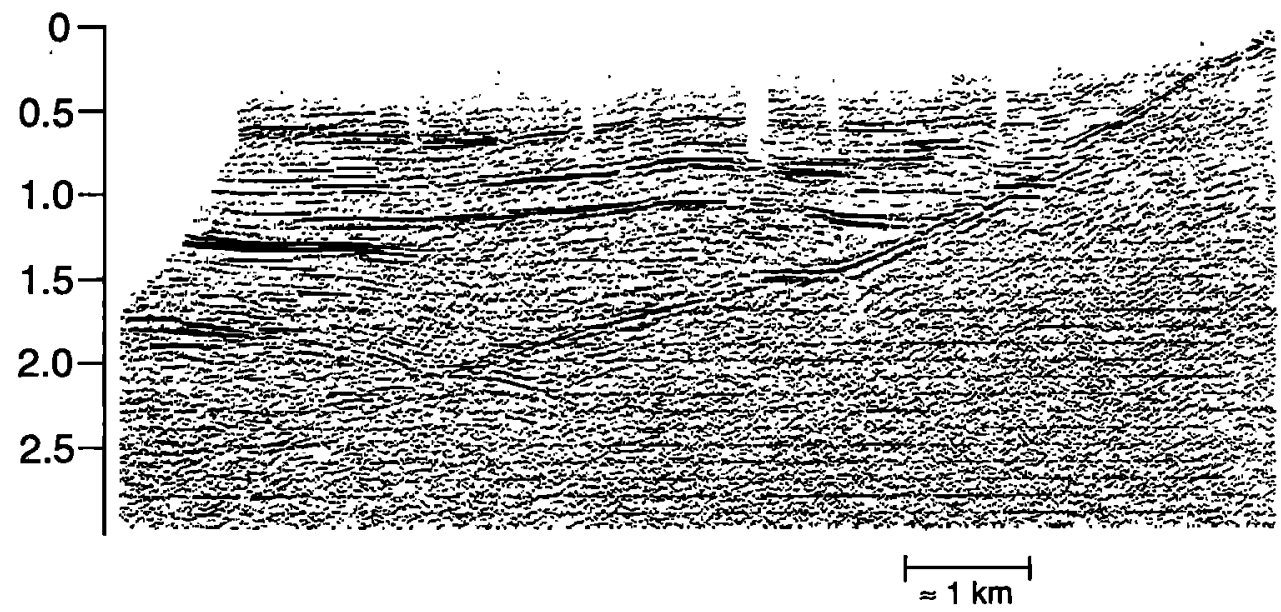

Figure 7. Seismic reflection profiles of low-angle normal faults. Vertical scales are all two-way travel times, in seconds. (a) Gulf of Bohai, east of Beijing, China, from Zhang [1994]; (b) Gulf of Oman, from Wernicke and Burchfiel [1982]; (c) Lamoille Valley, Nevada, from Smith et al. [1989]. See text for discussion. 
$35^{\circ}$ near the surface, flattening downward to about $5^{\circ}$ [Zhang, 1994]. Although the total depth of the section is not known, the fault is imaged down to a two-way travel time of $5.5 \mathrm{~s}$, including a few hundred meters of water. At $3-5 \mathrm{~km} / \mathrm{s}$ average velocity, this yields a depth range for the section of 9-15 km.

The Gulf of Oman example (Figure $7 \mathrm{~b}$ ) lies along the northeastern passive margin of the Arabian Peninsula. Following Late Cretaceous obduction of the Semail ophiolite, the Oman Mountains and bordering shelf region experienced basementinvolved extension in Late Cretaceous and Tertiary time [e.g., Mann et al., 1990]. The imaged fault is conceivably associated with large-scale slumping toward the trench rather than basement-involved continental extension, perhaps analogous to the Gulf of Mexico. However, evidence for a protracted history of basement-involved extension nearby on land, and the absence of major evaporites or diapirism in the Gulf of Oman [e.g., Mann et al., 1990; White and Ross, 1979] suggest an analogy with Gulf of Mexico is inappropriate. The fault plane is clearly imaged to about $4 \mathrm{~s}$ two-way travel time or a probable depth range of $6-10 \mathrm{~km}$.

The Basin and Range example (Figure 7c) is from the center of the province along the topographically sharp range front of the Ruby Mountains-East Humboldt Range core complex [Smith et al., 1989; Mueller and Snoke, 1993]. Hanging wall sediments are nonmarine Cenozoic basin fill, while footwall rocks are migmatitic gneisses of the core complex. Detailed velocity analysis for this example suggests the fault is a lowangle structure dipping about $10^{\circ}-22^{\circ}$ in the upper $4 \mathrm{~km}$ of the crust [Smith et al., 1989]. The fault projects toward a fault scarp in alluvium, suggesting activity in late Quaternary time. Numerous other examples of either young or once-active lowangle normal faults have been described from the Basin and Range based on combined subsurface and neotectonic data [e.g., Effimov and Pinezich, 1986; Burchfiel et al., 1987; Johnson and Loy, 1992; Bohannon et al., 1993].

It is difficult to argue that any of the above examples have been passively rotated (i.e., while inactive) from a steep dip. Hanging wall sediments and the topographic surface in all examples preclude significant tilting of the fault planes during their latest phases of movement, which would require unrealistic paleotopography and depositional slope. In all examples, however, it is difficult to constrain the intial dip of the fault. The apparent fault bed angle along the low-angle segments suggests relatively modest net rotations of about $20^{\circ}-40^{\circ}$. However, because the faults are listric, these dips may be due to rollover of an independently deforming hanging wall block, rather than a measure of the rotation of the fault plane [e.g., Xiao et al., 1991].

It is emphasized that these three examples are not particularly unique. Images from basement-involved, upper crustal low-angle $\left(0-30^{\circ}\right)$ normal faults have been published from all three tectonic settings elsewhere (e.g., boundary faults of the Rio Grande rift [Russell and Snelson, 1990]; Outer Isles fault in the shelf region off Scotland [Brewer and Smythe, 1984]; the Slocan Lake fault in the Canadian Cordillera [Cook et al., 1992]). As in the case of the Sevier Desert detachment, a number of examples show fault plane reflections continuously traceable at shallow dip from near the surface to depths of 15-20 km [e.g., Brewer and Smythe, 1984; Cook et al., 1992]. It is also stressed that reflection data indicate there are a large number of normal faults with moderate to steep dips through the upper 10-15 km of the crust [e.g., Anderson et al., 1983; Okaya and Thompson, 1985; Brun et al., 1991]. a)
b)
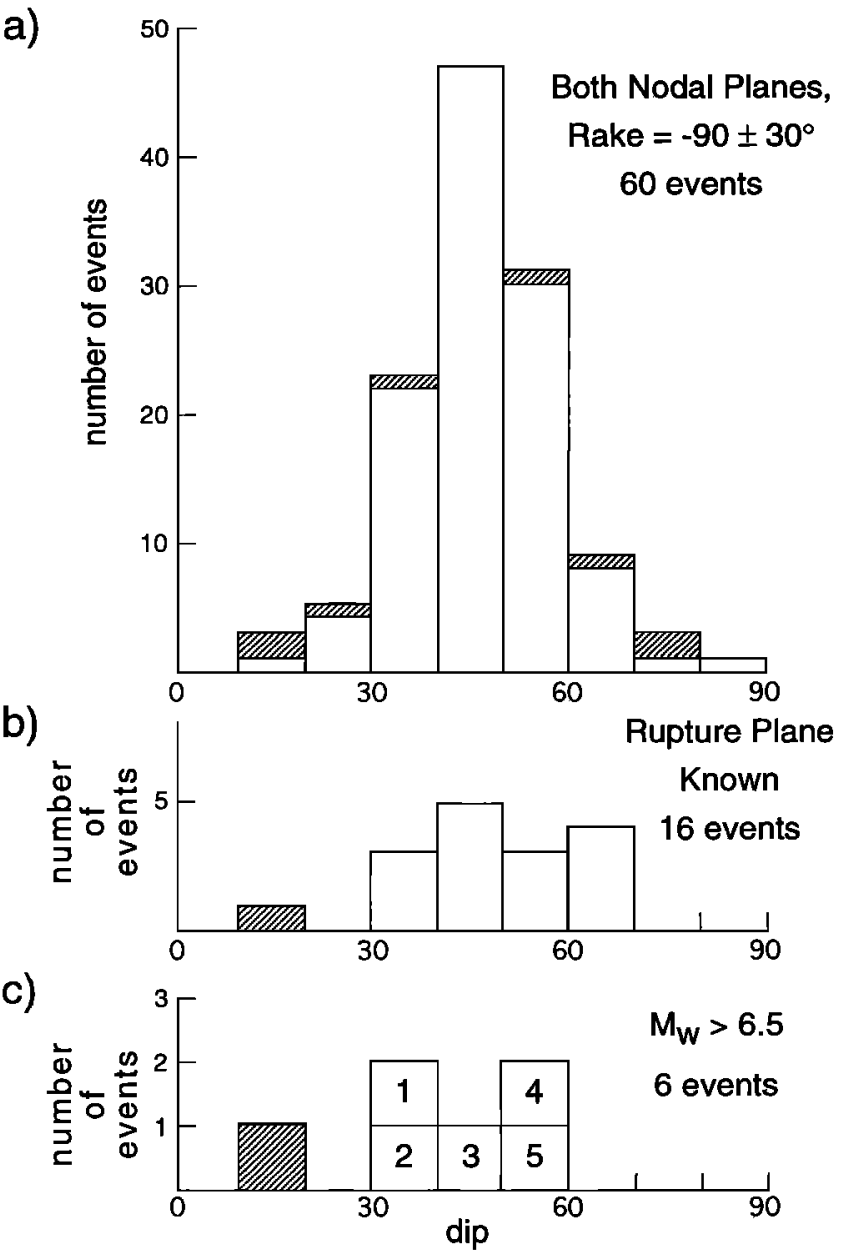

Figure 8. Frequency of earthquakes versus dip, crosshatched events from Abers [1991]. (a) Both nodal planes, from Jackson and White [1989] and Abers [1991]; (b) events with known focal plane, including event 1 of Abers [1991]; (c) events larger than moment magnitude 6.5, from Doser and Smith [1989] (Basin and Range events), Jackson and White [1989], and Abers [1991], including 1, Aegean Sea, 1970; 2, Aegean Sea, 1969; 3, Hebgen Lake, 1959; 4, Borah Peak, 1983; and 5, Italy, 1980.

\section{Seismicity}

The weight of evidence from field geology, thermochronologic studies, paleomagnetic studies, and seismic reflection profiling suggests active slip of major normal faults dipping less than $30^{\circ}$ and in some cases initiation of these faults at shallow dip, especially along their deeper parts. However, the majority of focal planes from a compilation of all normal fault earthquakes with a mechanism defined by detailed waveform modeling dip between $30^{\circ}$ and $60^{\circ}$ (Figure 8). Three of the eight shallowly dipping planes are from focal mechanism studies for events in 1982 and 1985 in the Woodlark-D'Entrecasteaux extensional province of Papua New Guinea [Abers, 1991], determined after Jackson and White's [1989] synthesis. Of four dip-slip events studied, two had nodal planes dipping about $15^{\circ}-20^{\circ}$, and another two dipped about $30^{\circ}$. Although no surface rupture is known from these events, they are the only large earthquakes known to have occurred in a tectonic environment of Pliocene and Quaternary metamorphic core complexes [Hill et al., 1992; Baldwin et al., 1993]. The largest event, with $M_{w}=$ 


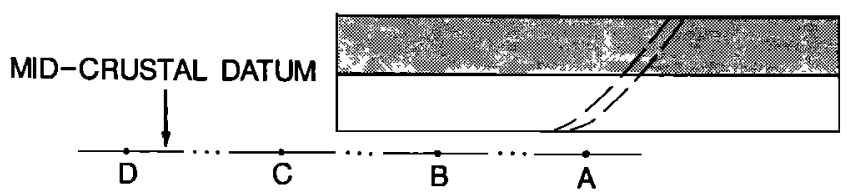

(1)

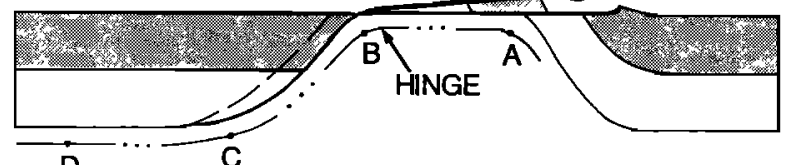

(2)

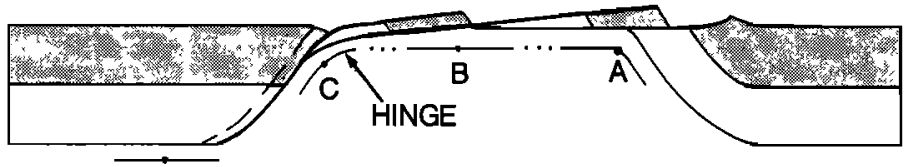

D

(3)

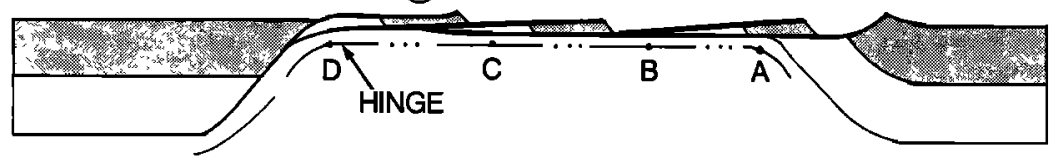

Figure 9. Rolling hinge model of detachment faulting [from Wernicke, 1992]. See text for discussion.

6.8 , was positioned such that its shallow nodal plane projects into the young detachment described by Hill et al. [1992], and thus the shallow plane was suggested to be the more likely rupture plane [Abers, 1991].

The addition of the Papua New Guinea data to the earlier compilation (Figure 8a), even for those events in which the rupture plane is known (Figure $8 b$ ), nonetheless reveals a predominance of moderate to steeply inclined planes, as has been reported in a number of previous reviews [Jackson, 1987; Jackson and White, 1989; Doser and Smith, 1989].

As emphasized by Jackson [1987] and Jackson and White [1989], large normal fault earthquakes nucleate near the base of the seismogenic layer and cut most or all of the way through it. They also noted that the largest known normal fault ruptures have strike lengths of the same order as their dip lenths, with few exceeding about $20 \mathrm{~km}$. Thus if we consider a $45^{\circ}$ fault cutting a seismogenic layer $15 \mathrm{~km}$ thick, we expect a seismic moment [e.g., Scholz, 1990]

$$
M_{0}=\mu A D \approx 5 \times 10^{18} \mathrm{~N} \mathrm{~m},
$$

assuming an average fault slip $D$ of $2 \mathrm{~m}$, a roughly equant fault plane of area $A$, and a rigidity $\mu$ of about $6 \mathrm{GPa}$. This corresponds to a moment magnitude $M_{w}=\sim 6.5$.

In the compilation of Jackson and White [1989], which included 56 dip-slip normal events (rake within $30^{\circ}$ of $-90^{\circ}$ ), only a dozen or so of these are of $M_{w} \geq 6.5$, and these dominate the recorded moment release on normal fault earthquakes. Globally, there are only six normal dip-slip events with $M_{w}=6.5$ or greater where the plane is resolved (Figure $8 \mathrm{c}$ ), if the large event described by Abers [1991] is included. As can be seen in Figure $8 \mathrm{c}$, nodal planes dipping $30^{\circ}-60^{\circ}$ are still most common, as in the larger sample that includes mostly small events. However, the Papua New Guinea event represents a much more substantial fraction of the sample for the large events, which is far more evenly distributed with respect to dip.

\section{Discussion}

\section{Paradox of Seismicity and the Geologic Record}

Many factors have been proposed to reconcile the predominance of moderately dipping planes defined by seismicity with the existence of low-angle normal faults. These include (1) "rolling hinge" or "flexural rotation" models, (2) a nonuniformitarian lack of active low-angle normal faults, (3) aseismic creep along low-angle faults, and (4) long recurrence intervals between earthquakes on low-angle faults (e.g., discussions by Jackson [1987], Buck [1988], Doser and Smith [1989], King and Ellis [1990], and Wernicke [1992]).

Rolling hinge models. Rolling hinge models suggest that isostatic unloading during and after slip induces shortwavelength flexure and tilting of the footwall [e.g., Buck, 1988; Wernicke and Axen, 1988; Hamilton, 1988], so that many ancient normal faults with subhorizontal dip may have been much steeper while active (Figure 9). For example, according to Buck's [1988] model, based on physical reasoning, all normal faults are essentially planar and project steeply through the brittle, seismogenic part of the crust with moderate to steep dip, terminating at the base of the brittle layer. Flexural rotation of the footwall produces a series of sequentially detached fault blocks, all of which are bounded by high-angle faults. The Andersonian theory and seismicity data are thereby resolved with the formation of subhorizontal detachments and core complexes, as the model does not require active slip on lowangle fault planes. A similar conclusion was reached by King and Ellis [1990].

In contrast, the model of Wernicke and Axen [1988], based on geological observations along the boundary between the Basin and Range province and Colorado Plateau [cf. King and Ellis, 1990] stresses a relationship between the dip of footwall bedding of normal faults and their initial dips. The footwalls of initially steep normal faults were deformed in abrupt shortwavelength flexures and large, subvertical fractures (e.g., the 
northern Virgin Mountains, Nevada), while those with shallow initial dips resulted in broad footwall upwarps (e.g., western Mormon Mountains and Sevier Desert areas). Subsequent studies have documented both flexure and shear in a number of detachment footwalls, consistent with the concept of a rolling hinge [Bartley et al., 1990; Manning and Bartley, 1994; Selverstone et al., 1995].

Wernicke and Axen [1988, p. 851] concluded that the transient steepness of at least some ancient detachments in the brittle crust may ameliorate the paradox with focal mechanisms but that this does not reconcile the seismic data with those faults active at low dip in the brittle crust, such as the Sevier Desert, Mormon Peak, Whipple Mountains, and Panamint Valley detachments [cf. Johnson and Loy, 1992; Scott and Lister, 1992]. Given the evidence summarized above for active slip on low-angle normal faults, rolling hinge models that exclude shallow faulting seem not to provide a satisfactory explanation of the seismicity data.

Paucity of active low-angle normal faults. Another explanation is that none of the currently active zones of continental extension include low-angle normal faults. Since most examples of low-angle normal faults in the literature are ancient, as for phylum Trilobita, there may be no reason to suspect they are active at present. However, a number of examples, including those from Papua New Guinea [Hill et al., 1992]; the Sevier Desert, Panamint Valley [Burchfiel et al., 1987], and Lamoille Valley (Figure 7c) in the Basin and Range; and the Gulf of Oman (Figure 7a) appear to involve Quaternary deposits. Hence unlike the trilobites, examples from the most recent period of earth history do not appear to be particularly rare, and so their sudden disappearance would be rather fortuitous.

A subset of this explanation is that low-angle normal faults are favored in certain tectonic settings that are currently not active [e.g., Burchfiel et al., 1992]. The examples discussed above (e.g., Figure 7), however, seem to occur in a variety of tectonic environments, including orogenic collapse, intracratonic rift, and passive margin settings, all of which are now active globally. Thus the nonuniformitarian hypothesis that shallowly dipping nodal planes are rare because low-angle normal faults are simply nowhere currently active does not seem particularly appealing.

Aseismic brittle creep. Another way to explain the seismicity is that low-angle normal faults tend to creep aseismically [e.g., Jackson, 1987; Doser and Smith, 1989]. This explanation has interesting implications for the physics of earthquake rupture, although it is at present not obvious what the cause might be.

The major effect would presumably be the brittle constitutive rheology of the fault zone. Such an effect would presumably be temperature dependent and therefore depth dependent. For example, a transition from stick-slip to stable frictional sliding with depth, hypothesized for the San Andreas fault zone [Tse and Rice, 1986] may in some way apply to normal faults, such that their flat segments are less prone to seismic slip than steeper segments in the upper crust. Such a rheological effect would have to apply to a wide variety of rock compositions, as detachments seem to be developed in every major rock type [e.g., Davis, 1980]. However, the observation that large events on steep faults penetrate to $10-15 \mathrm{~km}$ depth [Jackson and White, 1989], well below the range of depths discussed above for shallowly dipping normal faults, seems to argue against such an explanation.

Alternatively, it may be that either the low dip or the orien- tation of stress axes favors creep for reasons currently unknown. However, thrust earthquakes display a wide range of dip, with low-angle thrusts responsible for the largest known earthquakes. The fact that both thrust and normal fault earthquakes occur argues against isolating stress orientation as cause of aseismic behavior.

Long recurrence intervals. Another potential solution to the problem might be longer recurrence intervals for shallow faults and perhaps due to the greater efficiency of low-angle faults in absorbing elastic strain that accommodates horizontal extension. Since larger fault planes would be able to accommodate more strain, low-angle faults might fail more rarely, and in larger events, than steeper ones, explaining the dearth of low-angle planes in global seismicity [Doser and Smith, 1989; Wernicke, 1992]. In addition, Forsyth [1992] suggests that finite slip on low-angle normal faults is favored by the fact that less energy, and hence less regional stress, is required for a given amount of extension in comparison with slip on high-angle faults. Geometrically, seismic slip on low-angle normal faults is more efficiently invested in accommodating horizontal extension than slip on high-angle faults, requiring fewer earthquakes.

One difficulty with this solution is that it does not explain why there are very few small- to moderate-sized earthquakes $\left(M_{w}<6\right)$ which would be expected if there are numerous active low-angle normal faults. The solution to this difficulty mainly depends on whether seismicity is clustered in time near infrequent mainshocks or occurrs steadily through the interseismic interval. The former seems to be the most likely for large faults. For example, the two locked portions of the San Andreas fault, and perhaps the Cascadia subduction zone, are capable of generating large earthquakes, but most of the seismic moment release associated with them, including adjustments near the boundaries of coseismic slip, occurs within a few years of the mainshock, followed by long intervals where even microearthquakes are relatively uncommon.

In the next section, these concepts are integrated with some simple aspects of earthquake mechanics, providing a quantitative basis for empirical relations of earthquake frequency versus dip described by Jackson [1987], Doser and Smith [1989], Jackson and White [1989], and Thatcher and Hill [1991]. In general, this approach may offer a fairly simple resolution to the paradox.

\section{Seismicity of Dip-Slip Faults}

Model. Consider a hypothetical seismogenic layer of thickness $h$ transected by a fault dipping $\theta$ (Figure 10). The average stress drop $\Delta \sigma$ on the fault is proportional to the average slip $D$ and area of $\operatorname{slip} A$ [e.g., Scholz, 1990],

$$
\Delta \sigma \propto \mu \frac{D}{\sqrt{A}} .
$$

The area of slip, assuming it about equant, is related to fault dip by

$$
\sqrt{A}=h / \sin \theta
$$

which implies that for constant stress drop, layer thickness and rigidity modulus for a given earthquake,

$$
D \propto 1 / \sin \theta .
$$

In other words, large, low-angle fault planes may accumulate more strain between earthquakes than small steep ones. For a 


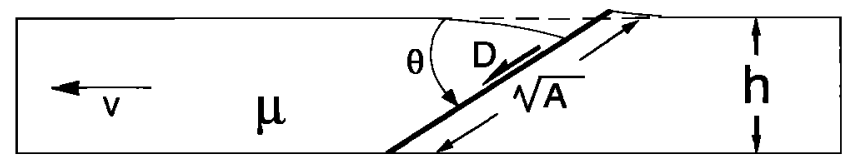

Figure 10. Diagram showing variables used to derive equations (2)-(6). See text for discussion.

constant rate of horizontal separation between hanging wall and footwall $v$, fewer earthquakes are required in a given time interval on shallow faults than on steep ones.

This relationship assumes, however, that strike length is free to expand with decreasing dip. The question arises as to whether the confinement of normal faults to relatively short segments [e.g., Machette et al., 1992] would limit their lateral dimensions and therefore their ability to slip according to (3). As reviewed by Jackson and White [1989], the largest known normal fault earthquakes have strike lengths restricted to the range of a few tens of kilometers, about 1-2 times their downdip rupture lengths. Thus a $15^{\circ}$ normal fault would have a downdip length of about $60 \mathrm{~km}$ and an along-strike length of 60-180 km. Shallow dip-slip ruptures have similar dimensions [e.g., Scholz, 1990, p. 297]. As mentioned above, the Sevier Desert detachment has been imaged as a single zone of reflections for a downdip length of $60-70 \mathrm{~km}$ and for a strike length of at least $100 \mathrm{~km}$ [Planke and Smith, 1991]. Assuming it is indeed a normal fault, it seems to have an appropriately long strike dimension relative to its dip dimension and is substantially longer than the steep faults described by Jackson and White [1989].

A second consideration is the fact that for each earthquake a greater amount of slip is transferred into horizontal extension for shallow faults than for steep ones. Thus

$$
\nu=D \cos \theta R^{\prime}
$$

where $R^{\prime}$ is the frequency of events per fault. This implies that for constant $v$,

$$
D \propto 1 /\left(R^{\prime} \cos \theta\right) .
$$

Equating (3) and (4) and solving for $R$,

$$
R^{\prime} \propto \tan \theta .
$$

Equation (5) allows comparison of earthquake frequency of two fault segments with contrasting $\theta$ but equal $v, h$, and $\mu$. For example, a fault dipping $10^{\circ}-15^{\circ}$ would be expected to rupture about 7 times less frequently than a fault dipping $55^{\circ}-60^{\circ}$.

A third consideration is that for a given total strike length of faults, there should be fewer faults in the case of low-angle versus high-angle faults. The frequency of events per unit length of fault is

$$
R=R^{\prime} / \sqrt{A}=R^{\prime} \sin \theta,
$$

where $1 / \sqrt{A}$ is the number of faults per unit length of fault. Thus

$$
R \propto \sin \theta \tan \theta .
$$

For two rift zones of equal strike length with multiple fault segments, one characterized by $10^{\circ}-15^{\circ}$ faults and the other by $55^{\circ}-60^{\circ}$ faults, we would expect about 28 times more events per unit time in the rift with steep faults than in the rift with low-angle faults.

The above reasoning suggests that low-angle faults should fail less often but with larger earthquakes. Since the moment of an earthquake is defined as

$$
M_{0}=\mu A D,
$$

from (2) and (3) we have

$$
M_{0} \propto 1 / \sin ^{3} \theta .
$$

Again, given constant stress drop, rigidity modulus, thickness of the seismogenic layer, and extension velocity, low-angle faults will have substantially larger earthquakes than steep ones. In terms of moment magnitude $M_{w}$, faults dipping $10^{\circ}-$ $20^{\circ}$ will produce earthquakes about one magnitude point stronger than faults dipping $50^{\circ}-60^{\circ}$. Thus if $50^{\circ}$ faults would typically yield magnitude $6.0-7.0$ earthquakes, $10^{\circ}-20^{\circ}$ faults should produce magnitude 7.0-8.0 earthquakes.

Application to continental seismicity. Globally, earthquake stress drop and the presumed rigidity of the crust might not be expected to vary [e.g., Kanamori and Anderson, 1975], but the thickness of the seismogenic layer and the horizontal extension velocity probably vary from rift to rift. These and other factors would produce a wide range of maximum earthquake magnitudes in extensional provinces, with rapidly spreading areas producing more frequent earthquakes for a given fault dip. Of the five events studied by Abers [1991], the event with the shallowest nodal plane $\left(\sim 17^{\circ}\right)$ was $M_{w}=6.8$, while the other events were all between 5.5 and 6.0. In other words, $80 \%$ of the moment release occurred during the single low-angle event.

Equation (6) may be related to the global data set of dip-slip normal fault earthquakes (Figure 8), depending on the global distribution of fault dip over the total strike length of active faults. The simplest such distribution would be uniform, such that the same total length of fault plane would exist for each $10^{\circ}$ increment of dip. This distribution would not agree well with the event frequency data (Figure $8 \mathrm{a}$ ), because it predicts the vast majority of events would occur on planes dipping $60^{\circ}-90^{\circ}$. In this case, consideration of both nodal planes would place a minimum number of events in the $30^{\circ}-60^{\circ}$ interval rather than the observed maximum (Figure 8a).

The simplest distribution that would explain the data in Figure $8 \mathrm{a}$ in terms of equation (6) is one that is even from $0^{\circ}$ to $60^{\circ}$, greatly reduced from $60^{\circ}$ to $70^{\circ}$ (say, by an order of magnitude), and effectively zero from $70^{\circ}$ to $90^{\circ}$ (Figure 11a). According to Figure $8 \mathrm{a}$, the ratio of events in the $0^{\circ}-30^{\circ}$ domain to that of the $30^{\circ}-60^{\circ}$ domain is about 0.1 . Integrating the function $\sin \theta \tan \theta$ for these two domains also yields a ratio of shallow to steep events of about 0.1 (Figure 11b), in good agreement with the data. Adding the conjugate planes to such a model distribution doubles the number of events in the $30^{\circ}-60^{\circ}$ domain and adds whatever seismicity would exist in the $60^{\circ}-90^{\circ}$ domain to the $0^{\circ}-30^{\circ}$ domain, so the ratio of shallow to steep events is not appreciably different from the model without conjugate planes (Figure 11b). The principal difference between the model in Figure $11 \mathrm{~b}$ and the data in Figure $8 \mathrm{a}$ is the ratio of events in the $30^{\circ}-40^{\circ}$ domain to events in the $40^{\circ}-50^{\circ}$ domain, which is about 1 in the model and 2 in the data. The discrepancy is perhaps mitigated by the fact that the uncertainty in dip is as large as the $10^{\circ}$ bin size [e.g., Thatcher and Hill, 1991], and the total number of events is relatively 


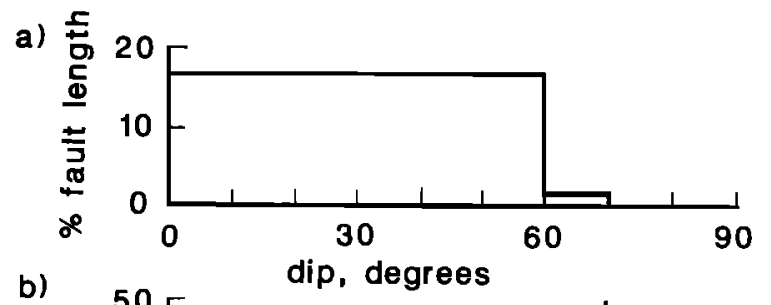

b)

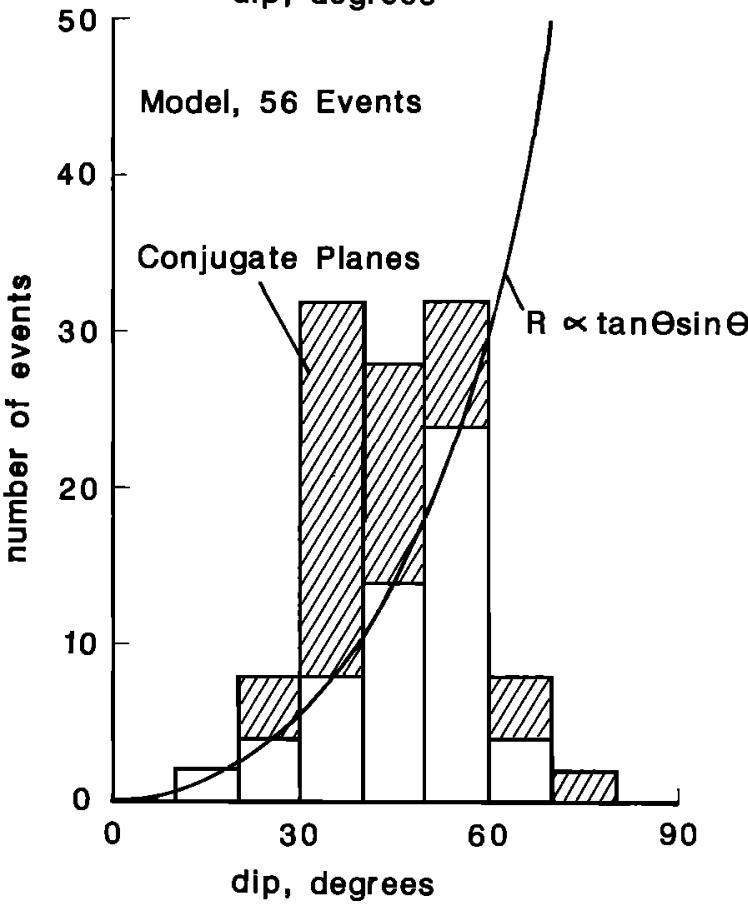

Figure 11. (a) Model for dip distribution of active normal faults that involve the entire seismogenic layer, discussed in text. (b) Number of earthquakes as a function of dip for 56 events (unpatterned areas) and conjugate planes (crosshatching), according to equation (6).

small. The principal point is that the model predicts the correct overall proportions of low-angle and high-angle planes.

The 16-event sample with resolved fault planes (Figure 8b) is perhaps too small to make a meaningful comparison with the model, but nonetheless is in good agreement. It is clear, however, that a 16-event sample over a few decades is not necessarily sufficient to observe a large earthquake on a low-angle normal fault. Even if the large Papua New Guinea event occurred on the steep plane, the model predicts only one or two of the events would be less than $30^{\circ}$ and none less than $20^{\circ}$. For the even smaller sample of events with $M_{w}>6.5$, the same conclusion holds.

Of course, there are distributions other than the one shown in Figure 11a that could reconcile the data with equation (6). For example, an even distribution in the $30^{\circ}-60^{\circ}$ domain with a smaller fraction from $60^{\circ}$ to $90^{\circ}$, with no faults from $0^{\circ}$ to $30^{\circ}$, would also be consistent with the data. Unlike the distribution shown in Figure 11a, however, such a distribution is not successful in reconciling geological observations of brittle lowangle normal faults with the seismicity.

Mechanical implications. If distributions of the type shown in Figure 11a do indeed represent the global distribution of a "major" ctive normal faults in continents, how do they bear on Andersonian fault mechanics? The existence of lowangle normal faults suggests that Andersonian theory, which predicts that normal faults form with a dip of $60^{\circ}$, would appear to be in need of substantial modification or abandonment.

One of its main assumptions, that the principal stress axes in the brittle crust are orthogonal to the Earth's surface, is likely to be the major problem. Over the last 5 years, the problem has attracted the attention of fault mechanists, in the tradition of Hafner [1951]. Solutions to the problem have included rotation of stress trajectories through flexure [Spencer and Chase, 1989], igneous dilation at depth [Parsons and Thompson, 1993] or viscous flow of deep crust against the seismogenic layer [Yin, 1989; Melosh, 1990], rotation of stress trajectories in the vicinity of the fault zone via high fluid pressure [Axen, 1992], and considerations of the energy efficiency of low-angle faults [Forsyth, 1992]. As yet, there is no consensus on which if any of these mechanisms are correct, but they do provide a framework for major progress in understanding fault mechanics and earthquakes. For example, the hypothesis that low-angle normal faults confine locally high fluid pressure and rotated stress trajectories [Axen, 1992] may be testable by moderate-depth drilling (5-6 km) into the Sevier Desert detachment of west central Utah [Zoback and Emmermann, 1994].

The fact that progressive extension tends to decrease the dip of fault planes reconciles Anderson theory with the preponderance of earthquakes on faults dipping much less than $60^{\circ}$ with there being relatively few faults steeper than $60^{\circ}$ [e.g., Thatcher and Hill, 1991]. To the extent that rotation of stress trajectories is common in continental rifts, this distribution may be substantially "smeared" well below $30^{\circ}$ (the cutoff for frictional sliding if stress trajectories are not rotated), consistent with the model distribution in Figure 11a. In this case, $60^{\circ}$ would represent the maximum initial dip, but lower initial dips and active slip not predicted by Anderson theory would be common.

\section{Conclusions}

Geologic reconstructions, thermochronology, paleomagnetism, and seismic reflection profiling indicate that initiation and slip on low-angle normal faults in the upper continental crust are common in the geologic record. The paradoxically low ratios of shallow and steep dipping focal planes to moderate ones in global seismicity may be resolved by a simple recurrence model, where the larger size and greater efficiency of shallow dip-slip faults cause them to fail much less frequently. This conclusion is perhaps not surprising when viewed in comparison with compressional dip-slip earthquakes. Approximately $80 \%$ of global seismic strain release over the last four decades occurred during two events, the 1960 Chilean earthquake and the 1964 Alaska earthquake, both of which occurred along shallowly dipping thrust faults.

The most probable reconciliation of this model with Andersonian fault mechanics lies in rotation of stress trajectories at depth in a significant fraction of active zones of continental extension.

The recognition of low-angle normal faults, and the prospect that they fail in large earthquakes, has significant implications for seismic hazard. Active low-angle normal faults may be difficult to detect on the basis of surface rupture patterns and paleoseismicity (e.g., the Sevier Desert detachment), as are low-angle thrust faults [e.g., Hauksson et al., 1987]. Since many geophysicists have expressed doubt that large seismogenic lowangle normal faults even exist [e.g., Jackson and McKenzie, 1983; Stein et al., 1988; Buck, 1988; Jackson and White, 1989; 
King and Ellis, 1990], hazards in extending areas such as the Basin and Range province, western Turkey, and China may be seriously underestimated.

Acknowledgments. Discussions with D. L. Anderson and $\mathrm{H}$. Kanamori helped clarify my thinking on seismological aspects of this paper. Reviews by G. A. Davis, R. K. Dokka, J. W. Geissman, T. A. Hauge, B. E. John, and JGR reviewers D. Davis, J. Oldow, and an anonymous referee contributed substantially toward improving the presentation. This research was supported by NSF grants EAR9219939 and EAR-9316797.

\section{References}

Abers, G. A., Possible seismogenic shallow-dipping normal faults in the Woodlark-D'Entrecasteaux extensional province, Papua New Guinea, Geology, 19, 1205-1208, 1991.

Allmendinger, R. W., Fold and thrust tectonics of the western United States exclusive of the accreted terranes, in The Geology of North America, vol. G-3, The Cordilleran Orogen: Conterminous U.S., edited by B. C. Burchfiel, P. W. Lipman, and M. L. Zoback, pp. 583-607, Geol. Soc. of Am., Boulder, Colo., 1992.

Allmendinger, R. W., and F. Royse, Jr., Comment on "Is the Sevier Desert reflection of west-central Utah a normal fault?" by M. Anders and N. Christie-Blick, Geology, 23, 669-670, 1995.

Allmendinger, R. W., J. W. Sharp, D. Von Tish, L. Serpa, L. Brown, S. Kaufman, J. Oliver, and R. B. Smith, Cenozoic and Mesozoic structure of the eastern Basin and Range province, Utah, from COCORP seismic-reflection data, Geology, 11, 532-536, 1983.

Allmendinger, R. W., H. Farmer, E. Hauser, J. Sharp, D. V. Tish, J. Oliver, and S. Kaufman, Phanerozoic tectonics of the Basin and Range-Colorado Plateau transition from COCORP data and geologic data: A review, in Reflection Seismology: The Continental Crust, Geodyn. Ser., vol. 14, edited by M. Barazangi and L. Brown, pp. 257-267, AGU, Washington, D. C., 1986.

Anders, M. H., and N. Christie-Blick, Is the Sevier Desert reflection of west-central Utah a normal fault?, Geology, 22, 771-774, 1994.

Anderson, E. M., The Dynamics of Faulting, 1st ed., 183 pp., Oliver and Boyd, Edinburgh, 1942.

Anderson, R. E., Thin-skin distension in Tertiary rocks of southwestern Nevada, Geol. Soc. Am. Bull., 82, 43-58, 1971.

Anderson, R. E., M. L. Zoback, and G. A. Thompson, Implications of selected subsurface data on the structural form and evolution of some basins in the northern Basin and Range province, Nevada and Utah, Geol. Soc. Am. Bull., 94, 1055-1072, 1983.

Armstrong, R. L., Cordilleran metamorphic core complexes-from Arizona to southern California, Annu. Rev. Earth Planet. Sci., 10, 129-154, 1982.

Asmerom, Y., J. K. Snow, D. K. Holm, S. B. Jacobsen, B. Wernicke, and D. R. Lux, Rapid uplift and crustal growth in extensional environments: An isotopic study from the Death Valley region, California, Geology, 18, 223-226, 1990.

Axen, G. J., Pore pressure, stress increase, and fault weakening in low-angle normal faulting, J. Geophys. Res., 97, 8979-8991, 1992.

Axen, G. J., Ramp-flat detachment faulting and low-angle normal reactivation of the Tule Springs thrust, southern Nevada, Geol. Soc. Am. Bull., 105, 1076-1090, 1993.

Axen, G. J., and B. Wernicke, Comment on "Tertiary extension and contraction of lower-plate rocks in the Central Mojave metamorphic core complex, southern California" by J. M. Bartley, J. M. Fletcher, and A. F. Glazner, Tectonics, 10, 1084-1086, 1991.

Axen, G. J., B. Wernicke, M. J. Skelly, and W. J. Taylor, Mesozoic and Cenozoic tectonics of the Sevier thrust belt in the Virgin River Valley area, southern Nevada, in Basin and Range Extensional Tectonics Near the Latitude of Las Vegas, Nevada, edited by B. Wernicke, Mem. Geol. Soc. Am., 176, 123-153, 1990.

Baldwin, S. L., G. S. Lister, E. J. Hill, D. A. Foster, and I. McDougall, Thermochronologic constraints on the tectonic evolution of active metamorphic core complexes, D'Entrecasteaux Islands, Papua New Guinea, Tectonics, 12, 611-628, 1993.

Bally, A. W., P. L. Gordy, and G. A. Stewart, Structure, seismic data, and orogenic evolution of the southern Canadian Rocky Mountains, Bull. Can. Pe. Geol., 4, 337-381, 1966.
Bally, A. W., D. Bernoulli, G. A. Davis, and L. Montadert, Listric normal faults, Oceanogr. Acta, SP, 87-102, 1981.

Bartley, J. M., J. M. Fletcher, and A. F. Glazner, Tertiary extension and contraction of lower-plate rocks in the central Mojave metamorphic core complex, southern California, Tectonics, 9, 521-534, 1990.

Bohannon, R. G., J. A. Grow, J. J. Miller, and R. H. Blank Jr., Seismic stratigraphy and tectonic development of Virgin River depression and associated basins, southeastern Nevada and northwestern Arizona, Geol. Soc. Am. Bull., 105, 501-520, 1993.

Brewer, J. A., and D. K. Smythe, MOIST and the continuity of crustal reflector geometry along the Caledonian-Appalachian orogeny, J. Geol. Soc. London, 141, 105-120, 1984.

Brock, W. G., and T. Engelder, Deformation associated with the movement of the Muddy Mountain overthrust in the Buffington window, southeastern Nevada, Geol. Soc. Am. Bull., 88, 1667-1677, 1977.

Brun, J. P., F. Wenzel, and ECORS-DEKORP Team, Crustal-scale structure of the southern Rhinegraben from ECORS-DEKORP seismic reflection data, Geology, 19, 758-762, 1991.

Buck, W. R., Flexural rotation of normal faults, Tectonics, 7, 959-975, 1988.

Burchfiel, B. C., K. V. Hodges, and L. H. Royden, Geology of the Panamint Valley-Saline Valley pull-apart system, California: Palinspastic evidence for low-angle geometry of a Neogene rangebounding fault, J. Geophys. Res., 92, 10,422-10,426, 1987.

Burchfiel, B. C., D. S. Cowan, and G. A. Davis, Tectonic overview of the Cordilleran orogen in the western United States, in The Geology of North America, vol. G-3, The Cordilleran Orogen: Conterminous U.S., edited by B. C. Burchfiel, P. W. Lipman, and M. L. Zoback, pp. 407-479, Geol. Soc. of Am., Boulder, Colo., 1992.

Compton, R. R., V. R. Todd, R. E. Zartman, and C. W. Naeser, Oligocene and Miocene metamorphism, folding, and low-angle faulting in northwestern Utah, Geol. Soc. Am. Bull., 88, 1237-1250, 1977.

Cook, F. A., J. L. Varsek, R. M. Clowes, E. R. Kanasewich, C. S Spencer, R. R. Parrish, R. L. Brown, S. D. Carr, B. J. Johnson, and R. A. Price, Lithoprobe crustal reflection cross section of the southern Canadian Cordillera, 1, Foreland thrust and fold belt to Fraser River fault, Tectonics, 11, 12-35, 1992.

Crittenden, M. D., Jr., P. J. Coney, and G. H. Davis (Eds.), Cordilleran Metamorphic Core Complexes, Mem. Geol. Soc. Am., 153, 490 pp., 1980.

Davis, G. A., and G. S. Lister, Detachment faulting in continental extension: Perspectives from the southwestern U. S. Cordillera, Spec. Pap. Geol. Soc. Am., 218, 133-159, 1988.

Davis, G. A., J. L. Anderson, E. G. Frost, and T. S. Shackelford, Mylonitization and detachment faulting in the Whipple-Buckskin Rawhide Mountains terrane, southeastern California and western Arizona, in Cordilleran Metamorphic Core Complexes, edited by M. D. Crittenden Jr., P. J. Coney, and G. H. Davis, Mem. Geol. Soc. Am., 153, 79-130, 1980.

Davis, G. A., G. S. Lister, and S. J. Reynolds, Structural evolution of the Whipple and South Mountains shear zones, southwestern United States, Geology, 14, 7-10, 1986.

Davis, G. H., Structural characteristics of metamorphic core complexes, in Cordilleran Metamorphic Core Complexes, edited by M. D. Crittenden Jr., P. J. Coney, and G. H. Davis, Mem. Geol. Soc. Am., $153,35-77,1980$.

Davis, G. H., and P. J. Coney, Geologic development of Cordilleran metamorphic core complexes, Geology, 7, 120-124, 1979.

Dibblee, T. W., Geologic map of the Daggett quadrangle, San Bernardino County, California, scale 1:62,500, U.S. Geol. Surv. Map, I-592, 1970.

Dickinson, W. R., Tectonic setting of faulted Tertiary strata associated with the Catalina core complex in southern Arizona, Spec. Pap. Geol. Soc. Am., 264, 106 pp., 1991.

Dokka, R. K., Patterns and modes of early Miocene crustal extension, central Mojave Desert, California, Spec. Pap. Geol. Soc. Am., 208, 75-95, 1986.

Dokka, R. K., Original dip and subsequent modification of a Cordilleran detachment fault, Mojave extensional belt, California, Geology, 21, 711-714, 1993.

Doser, D. I., and R. B. Smith, An assessment of source parameters of earthquakes in the Cordillera of the western United States, Bull. Seismol. Soc. Am., 79, 1383-1409, 1989.

Drewes, $\mathrm{H}$., and $\mathrm{C}$. H. Thorman, The Cordilleran orogenic belt be- 
tween Nevada and Chihuahua, Geol. Soc. Am. Bull., 89, 641-657, 1978.

Dumitru, T. A., P. B. Gans, D. A. Foster, and E. L. Miller, Refrigeration of the western Cordilleran lighosphere during Laramide shallow-angle subduction, Geology, 19, 1145-1148, 1991.

Effimoff, I., and A. R. Pinezich, Tertiary structural development of selected basins: Basin and Rage province, northeastern Nevada, Spec. Pap. Geol. Soc. Am., 208, 31-42, 1986.

Fitzgerald, P. G., J. E. Fryxell, and B. P. Wernicke, Miocene crustal extension and uplift in southeastern Nevada: Constraints from fission track analysis, Geology, 19, 1013-1016, 1991.

Fitzgerald, P. G., et al., Thermochronologic evidence for timing of denudation and rate of crustal extension of the south mountains metamorphic core complex and sierra estrella, Arizona, Nucl. Tracks Radiat. Meas., 21, 555-563, 1993.

Forsyth, D. W., Finite extension and low-angle normal faulting, Geology, 20, 27-30, 1992.

Foster, D. A., D. S. Miller, and C. F. Miller, Tertiary extension in the Old Woman Mountains area, California: Evidence from apatite fission track analysis, Tectonics, 10, 875-886, 1991.

Fritz, W. H., Geologic map and sections of the southern Cherry Creek and northern Egan Ranges, White Pine County, Nevada, Map 35, Nev. Bur. of Mines and Geol., Reno, 1968.

Fryxell, J. E., G. G. Salton, J. Selverstone, and B. Wernicke, Gold Butte crustal section, south Virgin Mountains, Nevada, Tectonics, 11, 1099-1120, 1992.

Gans, P. B., G. A. Mahood, and E. Schermer, Synextensional magmatism in the Basin and Range province: A case study from the eastern Great Basin, Spec. Pap. Geol. Soc. Am., 233, 1-53, 1989.

Hafner, W., Stress distributions and faulting, Geol. Soc. Am. Bull., 62, 373-398, 1951.

Hamilton, W., Detachment faulting in the Death Valley region, California and Nevada, U.S. Geol. Surv. Bull., 1790, 763-771, 1988.

Harms, T. A., and R. A. Price, The Newport fault: Eocene listric normal faulting, mylonitization, and crustal extension in northeast Washington and northwest Idaho, Geol. Soc. Am. Bull., 104, 745$761,1992$.

Hauge, T. A., Kinematic model of a continuous Heart Mountain allochthon, Geol. Soc. Am. Bull., 102, 1174-1181, 1990.

Hauksson, E., et al., The Whittier Narrows earthquake in the Los Angeles metropolitan area, Science, 239, 1409-1412, 1987.

Hill, E. J., S. L. Baldwin, and G. S. Lister, Unroofing of active metamorphic core complexes in the D'Entrecasteaux Islands, Papua New Guinea, Geology, 20, 907-910, 1992.

Holm, D. K., and R. K. Dokka, Interpretation and tectonic implications of cooling histories: An example from the Black Mountains, Death Valley extended terrane, California, Earth Planet. Sci. Lett., $116,63-80,1993$.

Holm, D. K., and B. Wernicke, Black Mountains crustal section, Death Valley extended terrain, California, Geology, 18, 520-523, 1990.

Holm, D. K., J. K. Snow, and D. R. Lux, Thermal and barometric constraints on the intrusive and unroofing history of the Black Mountains: Implications for timing, initial dip, and kinematics of detachment faulting in the Death Valley region, California, Tectonics, 11, 507-522, 1992.

Holm, D. K., J. W. Geissman, and B. Wernicke, Tilt and rotation of the footwall of a major normal fault system: Paleomagnetism of the Black Mountains, Death Valley extended terrane, California, Geol. Soc. Am. Bull., 105, 1373-1387, 1993.

Howard, K. A., and B. E. John, Crustal extension along a rooted system of imbricate low-angle faults: Colorado River extensional corridor, California and Arizona, in Continental Extensional Tectonics, edited by M. P. Coward, J. F. Dewey, and P. L. Hancock, Geol. Soc. Spec. Publ. London, 28, 299-311, 1987.

Howard, K. A., P. Stone, M. A. Pernokas, and R. F. Marvin, Geologic and geochronologic reconnaisance of the Turtle Mountains area, California, west border of the Whipple Mountain detachment terrane, in Mesozoic-Cenozouc Tectonic Evolution of the Colorado River Trough Regıon, California, Arizona and Nevada, edited by E. G. Frost and D. L. Martin, pp. 341-354, Cordilleran Publ., San Diego, Calif., 1982.

Jackson, J. A., Active normal faulting and crustal extension, in Continental Extensional Tectonics, edited by M. P. Coward, J. F. Dewey, and P. L. Hancock, Geol. Soc. Spec. Publ. London, 28, 3-17, 1987.

Jackson, J. A., and D. McKenzie, The relationship between strain rates, crustal thickening, paleomagnetism, finite strain and fault movements within a deforming zone, Earth Planet. Sci. Lett., 65, 182-202, 1983.

Jackson, J. A., and N. J. White, Normal faulting in the upper continental crust: Observations from regions of active extension, J. Struct. Geol., 11, 15-36, 1989.

John, B. E., Geometry and evolution of a mid-crustal extensional fault system: Chemehuevi Mountains, southeastern California, in Continental Extensional Tectonics, edited by M. P. Coward, J. F. Dewey, and P. L. Hancock, Geol. Soc. Spec. Publ. London, 28, 313-335, 1987.

John, B. E., and D. A. Foster, Structural and thermal constraints on the initiation angle of detachment faulting in the southern Basin and Range: The Chemehuevi Mountains case study, Geol. Soc. Am. Bull., 105, 1091-1108, 1993.

Johnson, R. A., and K. L. Loy, Seismic reflection evidence for seismogenic low-angle faulting in southeastern Arizona, Geology, 20, 597$600,1992$.

Kanamori, H., The energy release in great earthquakes, J. Geophys. Res., 82, 2981-2987, 1977.

Kanamori, H., and D. Anderson, Theoretical basis of some empirical relations in seismology, Seismol. Soc. Am. Bull., 65, 1073-1095, 1975.

Kemnitzer, L. E., Structural studies in the Whipple Mountains, southeastern California, Ph.D. thesis, 150 pp., Calif. Inst. of Technol., Pasadena, 1937.

King, G., and M. Ellis, The origin of large local uplift in extensional regions, Nature, 348, 689-692, 1990.

Lachenbruch, A. H., and J. H. Sass, Models of an extending lithosphere and heat flow in the Basin and Range province, Mem. Geol. Soc. Am., 152, 1978.

Livaccari, R. F., J. W. Geissman, and S. J. Reynolds, Paleomagnetic evidence for large-magnitude, low-angle normal faulting in a metamorphic core complex, Nature, 361, 56-59, 1993.

Livaccari, R. F., J. W. Geissman, and S. J. Reynolds, Large-magnitude extensional deformation in the South mountains metamorphic core complex, Arizona: Evaluation with paleomagnetism, Geol. Soc. Am. Bull., 107, 877-894, 1995.

Longwell, C. R., Low-angle normal faults in the Basin and Range province, Eos Trans. AGU, 26, 107-118, 1945.

Machette, M. N., S. F. Personius, and A. R. Nelson, The Wasatch fault zone, Ann. Tectonicae, 6, suppl., 5-39, 1992.

Malaveielle, J., Extensional shearing deformation and kilometer-scale "a"-type folds in a Cordilleran metamorphic core complex (Raft River Mountains, northwestern Utah), Tectonics, 6, 423-448, 1987.

Mancktelow, N. S., and T. L. Pavlis, Fault-fold relationships in lowangle detachment systems, Tectonics, 13, 668-685, 1994.

Mann, A., S. S. Hanna, and S. C. Nolan, The post-Campanian tectonic evolution of the Central Oman Mountains: Tertiary extension of the eastern Arabian margin, in The Geology and Tectonics of the Oman Region, edited by A. H. F. Robertson et al., Geol. Soc. Spec. Publ. London, 49, 549-563, 1990.

Manning, A. H., and J. M. Bartley, Postmylonitic deformation in the Raft River metamorphic core complex, northwestern Utah: Evidence of a rolling hinge, Tectonics, 13, 596-612, 1994.

McDonald, R. E., Tertiary tectonics and sedimentary rocks along the transition Basin and Range province to Plateau and Thrust belt province, Utah, in Symposium on Geology of the Cordilleran Hingeline, edited by J. G. Hill, pp. 281-317, Rocky Mountain Assoc. of Geol., Denver, Colo., 1976.

McGee, W. J., On the origin and hade of normal faults, Am. J. Science, 26, 294-298, 1883

McKenzie, D. P., Some remarks on the development of sedimentary basins, Earth Planet. Sci. Lett., 40, 25-32, 1978a.

McKenzie, D. P., Active tectonics of the Alpine-Himalayan belt: The Aegean Sea and surrounding regions, Geophys. J. R. Astron. Soc., 55, $217-254,1978 b$.

Melosh, H. J., Mechanical basis for low-angle normal faulting in the Basin and Range province, Nature, 343, 331-335, 1990.

Miller, E. L., P. B. Gans, and J. D. Garing, An exhumed brittle-ductile transition in the Snake Range, Nevada, Tectonics, 2, 239-263, 1983.

Misch, P., Regional structural reconnaissance in central-northeast Nevada and some adjacent areas-Observations and interpretations, in Guidebook to the Geology of East-Central Nevada: 11th Annual Field Conference, pp. 17-42, Intermountain Assoc. of Pet. Geol. and East. Nev. Geol. Soc., Salt Lake City, Utah, 1960.

Morton, W. H., and R. Black, Crustal attenuation in Afar, in Afar Depression of Ethıopia, Proc. Sci. Rep. 14, edited by A. Pilgar and 
A. Rosler, pp. 55-65, E. Schweizerbart'sche, Stuttgart, Germany, 1975.

Mueller, K. J., and A. W. Snoke, Progressive overprinting of normal fault systems and their role in Tertiary exhumation of the East Humboldt-Wood Hills metamorphic complex northeast Nevada, Tectonics, 12, 361-371, 1993.

Mutter, J. C., and J. A. Karson, Structural processes at slow-spreading ridges, Science, 257, 627-634, 1992.

Noble, L. F., Structural features of the Virgin Spring area, Death Valley, California, Geol. Soc. Am. Bull, 52, 941-1000, 1941.

Okaya, D. A., and G. A. Thompson, Geometry of Cenozoic extensional faulting: Dixie Valley, Nevada, Tectonics, 4, 107-125, 1985.

Otton, J. K., Western frontal fault of the Canyon Range: Is it the breakaway zone of the Sevier Desert detachment?, Geology, 23, $547-550,1995$.

Parsons, T., and G. A. Thompson, Does magmatism influence lowangle normal faulting? Geology, 21, 247-250, 1993.

Pierce, W. G., Heart Mountain and South Fork detachment thrusts of Wyoming, Am. Assoc. Pet. Geol Bull., 41, 591-626, 1957.

Planke, S., and R. B. Smith, Cenozoic extension and evolution of the Sevier Desert Basin, Utah, from seismic reflection, gravity, and well log data, Tectonics, 10, 345-365, 1991.

Price, R. A., The Cordilleran foreland fold and thrust belt in the southern Canadian Rock Mountains, in Thrust and Nappe Tectonics, edited by K. R. McClay and N. J. Price, pp. 427-448, Geol. Soc. of London, 1981.

Proffett, J. M., Jr., Cenozoic geology of the Yerington district, Nevada, and implications for the nature and origin of Basin and Range faulting, Geol. Soc. Am. Bull., 88, 247-266, 1977.

Ransome, F. L., W. H. Emmons, and W. H. Garrey, Geology and ore deposits of the Bullfrog district, Nevada, U.S. Geol. Surv. Bull., 407, 130 pp., 1910.

Reynolds, S. J., Geology of the South Mountains, central Arizona, Ariz. Bur. Geol. Miner. Technol. Bull., 195, 61 pp., 1985.

Richard, S. M., J. E. Fryxell, and J. F. Sutter, Tertiary structure and thermal history of the Harquahala and Buckskin Mountains, west central Arizona: Implications for denudation by a major detachment fault system, J. Geophys. Res., 95, 19,973-19,987, 1990.

Royse, F., Jr., An overview of the geologic structure of the thrust belt in Wyoming, northern Utah, and eastern Idaho, in Geology of Wyoming, Mem. 5, edited by A. W. Snoke, J. R. Steidtmann, and S. M. Roberts, pp. 272-311, Geol. Surv. of Wyo., Laramie, 1993.

Royse, F., Jr., M. A. Warner, and D. L. Reese, Thrust belt structural geometry and related stratigraphic problems, Wyoming-Idahonorthern Utah, in Deep Drilling Frontiers in the Central Rocky Mountains, pp. 41-54, Rocky Mountain Assoc. of Geol., Denver, Colo., 1975.

Russell, L. R., and S. Snelson, Structural style and tectonic evolution of the Albuquerque Basin segment of the Rio Grande rift, in The Potential of Deep Seismic Profiling for Hydrocarbon Exploration, Proceedings of the Fifth IFP Exploration and Producton Research Conference, Publ. 165, Int. Lithosphere Program, edited by B. Pinet and C. Bois, pp. 175-208, Editions Technip, Paris, 1990.

Scholz, C. H., The Mechanics of Earthquakes and Faulting, 439 pp., Cambridge Univ. Press, New York, 1990.

Scott, R. J., and G. S. Lister, Detachment faults: Evidence for a low-angle origin, Geology, 20, 833-836, 1992.

Selverstone, J., G. Axen, and J. Bartley, P-T conditions of successive fracturing events during unroofing of an extensional mylonite zone: Constraints from oriented fluid inclusion planes, Geol. Soc. Am. Abstr. Programs, 25, A423, 1993.

Selverstone, J., G. Axen, and J. M. Bartley, Fluid inclusion constraints on the kinematics of footwall uplift beneath the Brenner Line normal fault, eastern Alps, Tectonics, 14, 264-278, 1995.

Smith, R. B., and R. L. Bruhn, Intraplate extensional tectonics of the eastern Basin and Range; Inferences on the structural style from siesmic reflection data, regional tectonics, and thermal-mechanical models of brittle-ductile deformation, J. Geophys. Res., 89, 57335762,1984

Smith, R. B., W. C. Nagy, K. A. Julander, J. J. Viveiros, C. A. Barker, and D. G. Gants, Geophysical and tectonic framework of the eastern Basin and Range-Colorado Plateau-Rocky Mountain transition, Mem. Geol. Soc. Am., 172, 205-233, 1989.

Spencer, J. E., Role of tectonic denudation in warping an uplift of low-angle normal faults, Geology, 12, 95-98, 1984.
Spencer, J. E., Miocene low-angle normal faulting and dike emplacement, Homer mountain and surrounding areas, southeastern California and southernmost Nevada, Geol. Soc. Am. Bull., 9, 1140$1155,1985$.

Spencer, J. E., and C. G. Chase, Role of crustal flexure in initiation of low-angle normal faults and implications for structural evolution of the Basin and Range province, J. Geophys. Res., 94, 1765-1775, 1989.

Spencer, J. E., and S. J. Reynolds, Tectonics of mid-Tertiary extension along a transect through west central Arizona, Tectonics, 10, 12041221, 1991.

Stein, R. S., G. C. P. King, and J. B. Rundle, The growth of geological structures by repeated earthquakes, 2, Field examples of continental dip-slıp faults, J. Geophys. Res., 93, 13,319-13,331, 1988.

Thatcher, W., and D. P. Hill, Fault orientations in extensional and conjugate strike-slip environments and their implications, Geology, 19, 1116-1120, 1991.

Tse, S. T., and J. R. Rice, Crustal earthquake instability in relation to the depth variation of frictional slip properties, J. Geophys. Res., 9l, 9452-9472, 1986.

Wernicke, B., Low-angle normal faults in the Basin and Range province: Nappe tectonics in an extending orogen, Nature, 291, 645-648, 1981.

Wernicke, B., Uniform-sense normal simple shear of the continental lithosphere, Can. J. Earth Sci., 22, 108-125, 1985.

Wernicke, B., Cenozoic extensional tectonics of the U.S. Cordillera, in The Geology of North America, vol. G3, The Cordilleran Orogen: Conterminous U.S., edited by B. C. Burchfiel, P. W. Lipman, and M. L. Zoback, pp. 553-582, Geol. Soc. of Am., Boulder, Colo., 1992.

Wernicke, B., and G. J. Axen, On the role of isostasy in the evolution of normal fault systems, Geology, 16, 848-851, 1988.

Wernicke, B., and B. C. Burchfiel, Modes of extensional tectonics, J. Struct. Geol., 4, 105-115, 1982.

Wernicke, B., J. D. Walker, and M. S. Beaufait, Structural discordance between Neogene detachments and frontal Sevier thrusts, central Mormon Mountains, southern Nevada, Tectonics, 4, 213-246, 1985.

White, R. S., and D. A. Ross, Tectonics of the western Gulf of Oman, J. Geophys. Res., 84, 3479-3489, 1979.

Worral, D. M., and S. Snelson, Evolution of the northern Gulf of Mexico, with emphasis on Cenozoic growth faulting and the role of salt, in The Geology of North America: An Overview, edited by A. W. Bally and A. R. Palmer, pp. 97-138, Geol. Soc. of Am., Boulder, Colo., 1989.

Wright, L. A., and B. W. Troxel, Shallow-fault interpretation of Basin and Range structure, southwestern Great Basin, in Gravtty and Tectontcs, edited by K. A. DeJong and R. Scholten, pp. 397-407, John Wiley, New York, 1973.

Wright, L. A., and B. W. Troxel, Geology of the northern half of the Confidence Hills $15^{\prime}$ quadrangle, Death Valley region, eastern California: The area of the Amargosa chaos, map sheet 34, Calif. Div. of Mines and Geol., Sacramento, 1984.

Xiao, H. B., F. A. Dahlen, and J. Suppe, Mechanics of extensional wedges, J. Geophys. Res., 96, 10,301-10,318, 1991.

Yin, A., Origin of regional rooted low-angle normal faults: A mechanical model and its tectonic implications, Tectonics, 8, 469-482, 1989.

Yin, A., and J. F. Dunn, Structural and stratigraphic development of the Whipple-Chemehuevi detachment fault system, southeastern California: Implications for the geometrical evolution of domal and basinal low-angle normal faults, Geol. Soc. Am. Bull., 104, 659-674, 1992.

Zhang, Y. K., Mechanics of extensional wedges and geometry of normal faults, J. Struct. Geol., 16, 725-732, 1994.

Zoback, M. D., and R. Emmermann, Scientific rationale for establishment of an international program of continental scientific drilling, in Report of the Intemational Meeting on Continental Sctentific Drilling, 194 pp., GeoForshungs Zentrum, Potsdam, Germany, 1994.

B. Wernicke, Division of Geological and Planetary Sciences, 170-25, California Institute of Technology, Pasadena, CA 91125. (e-mail: brian@legs.gps.caltech.edu)

(Received August 26, 1994; revised June 13, 1995; accepted June 20, 1995.) 